\title{
Early Modern Conceptualizations of Medieval History and Their Impact on Residential Architecture in the Polish-Lithuanian Commonwealth
}

\author{
Barbara Arciszewska
}

One of the key foundations of Sarmatism (a class discourse which constructed the identity of the Polish-Lithuanian elites as descendants of the ancient tribe of Sarmatians) ${ }^{1}$ was the cult of the past - the past of the family and the past of the nation understood as the nobility (szlachta), the only class with civic rights. The development of this specific attitude hinged on the role of medieval history as the most immediate source of prestige and legitimacy. ${ }^{2}$ Unlike antiquity, which in the territories of the Commonwealth produced very little material remains, the Middle Ages were a much more tangible era to the understanding of the early modern Poles, especially through evocative medieval buildings. Yet, as I will demonstrate below, while the Middle Ages did

1 Cynarski S., "Sarmatyzm - ideologia i styl życia", in Tazbir J. (ed.), Polska XVII wieku. Państwospoteczeństwo-kultura (Warsaw: 1977) 220-243; Maciejewski J., "Sarmatyzm jako formacja kulturowa. (Geneza i główne cechy wyodrębniające)”, Teksty. Teoria literatury - Krytyka Interpretacja 16 (1974) 13-42; cf. Tomkiewicz W., "Przełom renesansowy w świadomości ówczesnego społeczeństwa polskiego", in Jaroszewski T. (ed.), Renesans. Sztuka i ideologia (Warsaw: 1976) 9-17, here 12-13. On class and gender issues, see Arciszewska B., "The royal residence in Wilanów and gender constructions in early modern Poland", in Frommel S. (ed.), Homme bâtisseur, femme bâtisseuse: traditions et stratégies dans le monde occidental et oriental (Paris: Editions Picard, 2013) 137-150.

2 For a discussion of attitudes to the Middle Ages in the early modern period, see Jurkowlaniec G., Epoka nowożytna wobec średniowiecza. Pamiątki przesztości, cudowne wizerunki, dzieła sztuki (Wrocław: 2008) 39-46; Dobrowolski K., Studia nad kultura naukowa w Polsce do schytku XVI stulecia (Warsaw: 1933) 66; Herbst S., "Początki historycznego widzenia rzeczywistości w nauce i sztuce polskiego Odrodzenia", in Odrodzenie w Polsce, vol. II (Warsaw: 1956) 372-397; cf. Gębarowicz M., Poczatti malarstwa historycznego w Polsce (Wrocław: 1981) 37-38; and Kruszelnicki Z., Historyzm i kult przeszłości w sztuce pomorskiej XVI-XVIII wieku (Warsaw 1984) 40-42, 62-78. See also Żukowska J., "Tradycjonalizm kultury polskiego baroku”, Stupskie Studia Historyczne 11 (2004) 57-66.

(C) BARBARA ARCISZEWSKA, 2019 | DOI:10.1163/9789004378216_024

This is an open access chapter distributed under the terms of the prevailing CC-BY-NC-ND License at the time of publication. 
not function in early modern Polish historiography as a distinct period, ${ }^{3}$ the architecture of the Commonwealth was much more susceptible to medieval building traditions than evinced by textual sources. To address this complex intermeshing of discourses which developed around the question of the medieval past in early modern Poland (with a particular focus on residential architecture), my argument will be divided into three parts - the attitudes to the period we call the 'Middle Ages', the attitudes to medieval architecture, and the impact of both on early modern Polish residences.

\section{The Attitudes to the Middle Ages}

As has been shown in numerous studies, the Middle Ages were not perceived in the early modern Polish-Lithuanian Commonwealth as being a separate historical period. ${ }^{4}$ Janusz Tazbir, for instance, has demonstrated that the difference between this past era and the present one was not distinctive enough for the Polish elites. ${ }^{5}$ The dominant cyclical (rather than linear) conception of time, rooted in repeated agricultural tasks fundamental to the Polish economy, tended to elide the growing distance between today and the past. ${ }^{6}$ Time was conceived instead in terms of continuity of blood lines and stability of family

3 Śnieżko D., "Swojskie i obce w kronice uniwersalnej (przykład Marcina Bielskiego)", Teksty Drugie 79 (2003) 23-40 here 27-29.

4 The term itself was popularized by a professor at the University of Halle, Christoph Cellarius (Keller, 1638-1707), in his Historia universalis breviter ac perspicue exposita, in antiquam et mediiaeviac novam divisa, cumnotis perpetuis (Jena, Joachim Bielkius: 1702-1704). Concerning scholarly constructions of the term, see Kosseleck R., "Moderne Sozialgeschichte und historische Zeiten", in Rossi P. (ed.), Theorie der modernen Geschichtsschreibung (Frankfurt: 1987) 173-19o; cf. Moser D.R., "Mittelalter als Wissenschaftskonstruktion und Fiktion der Moderne", in Segl P. (ed.), Mittelalter und Moderne. Entdeckung und Rekonstruktion der mittelalterlichen Welt (Sigmaringen: 1997) 223-227.

5 Tazbir J., "Czas w kulturze staropolskiej”, in Tazbir J. (ed.), Studia nad kultura staropolska (Krakow: 2001), 176-196, here 184-192; idem, "Wizje przyszłości w kulturze staropolskiej", Odrodzenie i Reformacja w Polsce 20 (1982) 107-141, here 107-108, 117-118, 127-129; idem, "Polski renesans wobec przeszłości", in Libera Z. - Żurowski M. (eds.), Jan Kochanowski i kultura Odrodzenia. Materiaty z sesji naukowej zorganizowanej przez Uniwersytet Warszawski w dniach 19 do 21 marca 1981 roku w Warszawie (Warsaw: 1985) 31-47; see also Sierżęga P., "Litwa w sarmackiej myśli historycznej doby Oświecenia", Rocznik Lubuski 35, 10 (2009) 51-67, here 51-54; and Kwiatkowski S., "O kształtowaniu obrazu epoki średniowiecza," in Skibiński P. Przeszowska A. (eds.), Spojrzenie w przeszłość (Warsaw: 2007) 135-153, here 135-143.

6 Bogucka M., The Lost World of the Sarmatians, Custom as the Regulator of Polish Social Life in Early Modern Times (Warsaw: 1996) 7-15; eadem, "Uwagi o postrzeganiu czasu w Rzeczpospolitej szlacheckiej XVI-XVII wieku”, in Cackowski Z. - Wojczakowski J. (eds.), Stosunek do czasu w różnych strukturach kulturowych (Warsaw: 1987) 347-373. 
ties, underscoring the importance of ancestry and tradition. ${ }^{7}$ Symptomatic of this idea was a fairly lax attitude to the medieval past that was demonstrated by the otherwise distinguished historian Marcin Kromer (1512-1589), who used to dismiss complexities of medieval history with a casual 'let's drop the issues of very distant past. 8 The impressive intellectual legacy of the later Middle Ages, including historical research, therefore remained largely unpublished and little known..$^{9}$ It has been shown that among sources used by Polish authors in the early modern period, the most popular was the Bible, followed by ancient authorities, with almost no references to medieval historiography. ${ }^{10}$ The antique writers enjoyed such esteem that their authority legitimized any intellectual endeavour. ${ }^{11}$ Łukasz Górnicki (1527-1603), for instance, while discussing liberty', the core value of the szlachta, in his Dialogue between the Pole and the Italian that was supposedly recorded during the election of Sigismund III in 1587 , does not refer to the medieval tradition of noble privileges which secured

7 Augustyniak U., “Moja wizja epoki - jak ją interpretować (klucze interpretacyjne)", in zespół MHP (Muzeum Historii Polski/ Museum of Polish History) (ed.), Spojrzenie w przesztość (Warsaw: 2007) 336-351, here 338-339; Szacki J., Tradycja. Przeglad problematyki (Warsaw: 1971) 25-29. On the importance of genealogy in contemporary constructions of history, see Bardach J., "Uwagi o 'rodowym' ustroju społeczeństwa i prawie bliższości w Polsce średniowiecznej”, Czasopismo Prawno-Historyczne 4 (1952) 407-458. Kiersnowski R., "Tworzywo historyczne polskich legend herbowych", Rocznik Polskiego Towarzystwa Heraldycznego 13, 2 (1995) 11-25. Kuczyński S., Polskie herby ziemskie. Geneza, treści, funkcje (Warsaw: 1993). See also Samsonowicz H., O historii “prawdziwej” (Gdańsk: 1997) $135,151$.

8 '[...] sprawy odległe niechaj leżą odłogiem [...]', cf. Kromer Marcin, De origine et rebus gestis Polonorum libri XXX (Basel, Johannes Oporinus: 1555) 109, 115, 121, 151, 161, and passim. For details, see Finkel L., "Marcin Kromer, Historyk Polski XVI wieku. Rozbiór krytyczny", Rozprawy i Sprawozdania z posiedzeń Wydziatu Historyczno-Filozoficznego Akademii Umiejętności 16 (1883) 47; and Barycz H., Szlakami dziejopisarstwa staropolskiego. Studia nad historiografia w. XVI-XVIII (Wrocław: 1981) 72-123.

9 The important chronicle by Jan Długosz (1415-1480), for instance, was published in part only in 1614 (in full in 1711 in Leipzig), but it was not translated into Polish until 1867-1870, see Wyrozumski J., "55 lat pracy nad krytyczną reedycją dziejów Polski Jana Długosza", Nauka 2 (2006) 157 .

10 Krzysztofik M., "Recepcja Biblii w literaturze staropolskiej - przegląd problematyki", in: Signa Temporis. Rocznik Teologiczno-Humanistyczny 11 (2006) 7-26; Wichowa M., "Refleksje o przemijaniu i o pamięci przeszłości. Staropolski dialog z tradycją antyczną (na podstawie Nowych Aten Benedykta Chmielowskiego)", Acta Universitatis Lodziensis, Folia Litteraria Rossica, Special Issue (2015) 67-78.

11 Partyka J., "Tradycja antyczna jako argument w polemice z wrogami Rzeczpospolitej", Forum Artis Rhetoricae 3 (2011) 27-36; Tazbir J., Myśl polska w nowożytnej kulturze europejskiej (Warsaw: 1986) 75-76. 
these freedoms, but rather to Athens and Sparta as points of reference. ${ }^{12}$ It has to be remembered as well that Sarmatian identity was a product of territorial expansion and political rights received by the szlachta under the Jagiellonians (1386-1596); thus returning to the Piast era (ca. 960-1370) (despite perennial calls to choose "a Piast" during the royal elections) was deemed of little consequence for the realities of the Commonwealth. ${ }^{13}$

For reasons given above, the attitudes to a medieval past can be ascertained on the basis of scattered comments, in which the vaguely defined 'old times' are generally seen as a counterpoint to the present, albeit without clear distinctions. ${ }^{14}$ The focus was, understandably, on the heroic past, important for self-definition of the szlachta. The example of medieval knights, cast as paragons of military virtue, was vital for the error-prone political class of the contemporary Commonwealth, as was suggested by Szymon Starowolski (1585-1650), 'the Polish Lipsius.'. ${ }^{15}$ Medieval heroes in Starowolski's Sarmatiae Bellatores of 1631 fight, plunder, demolish, and destroy with fire and sword (the favourite phrase of this historian), and only rarely do they build something in their domains. ${ }^{16}$ This is obviously in line with the stories from old chronicles focusing on wars, plagues, famines, and other calamities. Middle Ages were therefore associated with hardships, yet at the same time they were linked to high moral standards and religiosity, which had since been lost. ${ }^{17}$

12 Górnicki Łukasz, O elekcyi, wolności, prawie i obyczajach polskich: rozmowa Polaka z Wtochem (Krakow, U dziedziców Jakuba Siebeneychera: 1616), fol. $<$ A4 r $>$.

13 Węcowski P., "Jagiellonowie wobec możnowładztwa w XIV-XVI wieku", in Mrozowski P. Tyszka P. - Węcowski P. (eds.), Europa Jagiellonica 1386-1572. Sztuka, kultura i polityka w Europie Środkowejza panowaniaJagiellonów (Warsaw: 2015) 83-96; Rybak P., Zjazdszlachty w Stężycy (maj-czerwiec 1575) na tle drugiego bezkrólewia (Warsaw: 2002) 141-143; cf. Chrościcki J., Sztuka i polityka. Funkcje propagandowe sztuki w epoce Wazów 1587-1668 (Warsaw: 1983) 46-48.

14 Christianity and Western cultural orientation were seen in the Commonwealth as a lasting legacy of the Middle Ages, creating a sense of continuity with the past, see Bogucka M., "Between the West and the East: The Outline of the Polish Cultural Identity Formation Till the End of the 18th Century", in Grathoff R. - Kłoskowska A. (eds.), The Neighbourhood of Cultures (Warsaw: 1994) 53-61.

15 Bielak F., "Działalność naukowa Szymona Starowolskiego", Studia i Materiaty z Dziejów Nauki Polskiej 1 (1957) 219-220.

16 Starowolski S., Sarmatiae Bellatores (Cologne, Henricus Crithius: 1631) 21-23, 53-56. The aim of the work was to counter international opinions questioning the military prowess of Poles (such as T. Lansius' Consultatio de principatu inter provincias Europae of 1613), cf. Starnawski J., "Szymon Starowolski, Wojownicy sarmaccy", Literary Studies in Poland 3 (1979) 182. For a similar narrative referring to the exploits of the Grand Dukes of Lithuania, see Dowgird Samuel, Genealogia albo krótkie opisanie wielkich książąt litewskich i ich wielkich a mężnych spraw woiennych (Lubcz, Piotr Blastus Kmita: 1626) n.p.

17 The olden days were universally praised for the selfless courage, bellicose (but devoid of cruelty) spirit, and civic attitudes of medieval nobility, while the contemporary szlachta 
To prevent further moral erosion, three complementary aspects of medieval history were repeatedly used by early modern authors as didactic tools to aid in the formation of male noble identity. The topoi of a perfect knight and a selfless state official were complemented by another pattern of conduct rooted in the feudal past, that of a landlord engaged in the cultivation of his estate. ${ }^{18}$ So the chivalric and civic ideals were complemented by the agrarian lifestyle model. ${ }^{19}$ Ponętowski's edition of Crescenzi's Book of rural benefits (1571) opens with a preamble extolling these complementary lifestyles rooted in medieval tradition. ${ }^{20}$ The tales of warring knights, diligently tending to their estates (and the common good) in times of peace established a benchmark of acceptable behaviour, a code of conduct imposed on successive generations. The imitation of the noble deeds of one's ancestors offered a guaranteed way to remain on the path to virtue and social recognition. While Bartosz Paprocki (1543-1614) in his influential armorial Seat of Virtue (Gniazdo Cnoty) of 1578 reiterated the importance of one's lineage by showing repeated rows of indistinct forefather figures, ${ }^{21}$ Wacław Kunicki $\left({ }^{1580-1653)}\right.$ in The Image of the Polish Nobleman of 1615 underscored the importance of medieval roots, 'from the Slavonic princes'.22 Yet he defined this medieval past in the broadest of terms - 'long ago', 'under the first Kings of Poland', or 'in the distant past' showing no real grasp of time. ${ }^{23}$

The situation is different with Marcin Bielski's Chronicle (1597), in which the text and especially the illustrations suggest a distinction between the

was accused of only caring about private interests; see, for instance, Starowolski Szymon, Votum o naprawie Rzeczypospolitey (Kraków, Maciej Jędrzejowczyk: 1625), fols. 3-5; cf. Partyka, "Tradycja antyczna" 33 .

18 Kurdybacha Ł., Staropolski ideat wychowawczy (Lviv: 1938) 15-19; Ossowska M., Ethos rycerski i jego odmiany (Warsaw: 1973) 15-22; cf. Kotowicz-Borowy I., "Znaczenie tradycji etosu szlacheckiego w poczuciu tożsamości grupowej i narodowej na dawnych pograniczach Rzeczypospolitej", Pogranicze. Studia spoteczne 19 (2012) 33-59, here 34-43; Tazbir J., "Wzorce osobowe szlachty polskiej w XVII wieku", Kwartalnik Historyczny 83, 4 (1976) 784-797.

19 Witkowska A., Stawianie my lubim sielanki (Warsaw: 1972) 86-87; Tazbir, "Wzorce" 789.

20 de' Crescenzi Pietro, O pomnożeniu y rozkrzewieniu wszelakich pożytków ksiag dwoienaście, ed.J. Ponętowski, trans. A. Trzecieski (Krakow, Stanislaus Scharffenberger: 1571) n.p. (dedication to Senator Jan Krzysztoporski, 1518-1585, the Wieluń castellan).

21 Paprocki B., Gniazdo Cnotyzkąd herby rycerstwa stawnego (Krakow, Andrzej Piotrkowczyk: 1578) 15-20, 28-31, and passim.

22 'od ... przezacnych Przodków, to iest właśnie od Xsiążąt Słowiańskich', Kunicki W., Obraz szlachcica polskiego (Krakow, Jacob Siebeneycher: 1615), fol. 3 .

23 Kunicki, Obraz, $<$ fol. $14 \mathrm{v}>,<$ fol. $22>$, fol. $22 \mathrm{v}$. The past is broadly defined as the period of 'our forefathers' ('czasy ojców naszyych'). There are mentions of the legendary rulers 'Kołodziej z Kruszwice' (fol. 36) and King Lech <fol. 39 v>, as well as 'Kazimierz Król' (Casimir the Great) $<$ fol. 22>. 
legendary antiquity and the more recent, and thus historical, Middle Ages. ${ }^{24}$ The images show the earliest legendary rulers of Poland (such as Popiel $)^{25}$ in vaguely antique garb, among buildings of both ancient and medieval provenance. ${ }^{26}$ Mieszko I (d. 992), ${ }^{27}$ the first Christian ruler, is shown among exotic splendour with a cross-staff which evidently acts to chase away the lurking demons. Bolesław Chrobry $(967-1025)^{28}$ wears ancient armour and is seated under a Roman tent, while Kazimierz I (1016-1058) ${ }^{29}$ is shown against a classical domed rotunda. ${ }^{30}$ These purely imaginary portraits are replaced by more historical renditions in those instances where some material evidence was available. ${ }^{31}$ Władysław Łokietek (1261-1333), ${ }^{32}$ for instance, was shown on a Gothic bench and the inscription running around the figure might have been based on the royal seal. ${ }^{33}$ There were also, of course, the royal tombs in the Wawel Cathedral to refer to. ${ }^{34}$ Similar sources were also used to depict subsequent rulers, as is evident in images of Casimir the Great $(1310-1370)^{35}$ and Louis of Anjou (1326-1382). ${ }^{36}$ Władysław Jagiełło (d. 1434) [Fig. 22.1] is seated

24 Bielski M., Kronika polska, ed. J. Bielski (Krakow, Jacob Siebeneycher: 1597). This was the updated edition of the universal chronicle first published in 1551 (further editions in 1554 and 1564); see Chrzanowski I., Marcin Bielski. Studyum historyczno-literackie (Lvov: 1926) 14-25, for details.

25 Bielski, Kronika 40.

26 On Bielski's interpretation of ancient and medieval pasts, see Śnieżko D., "Jak Marcin Bielski przerabiał z dobrego na lepsze", in Wiśniewska L. (ed.), Tożsamość i rozdwojenie. Rekonesans (Bydgoszcz: 2002) 211-220. Regarding the series of woodcuts in Bielski's Chronicle, see Miodońska B., "Władca i państwo w krakowskim drzeworycie książkowym XVI w.", in Jaroszewski, Renesans 45-96.

27 Bielski, Kronika 5 .

28 Idem 56 .

29 Idem 72.

30 On iconographic sources of the illustrations, see Chojecka E., "Drzeworyty Kroniki Marcina Bielskiego i zaginione gobeliny Anny Jagiellonki. Ze studiów nad związkami artystycznymi Krakowa i Brzegu w XVI wieku", Roczniki Sztuki Śląsiej 7 (1970) 59 f.; Bernasikowa M., "Sprawa arrasów w rozprawie Ewy Chojeckiej 'Drzeworyty Kroniki Joachima Bielskiego i zaginione gobeliny Anny Jagiellonki', Biuletyn Historii Sztuki 34 (1972) 301-304.

31 Miodońska, "Władca i państwo" 78, points to official royal seals as the primary iconographic source for Bielski's Chronicle images. See also Piech Z., Ikonografia pieczęci Piastów (Krakow: 1993) 148-150.

32 Bielski, Kronika 209.

33 Piekosiński F., Pieczęcie polskie wieków średnich. Doba Piastowska (Krakow: 1899) 189, Fig. 209.

34 Mrozowski P., Polskie nagrobki gotyckie (Warsaw: 1994) 25, 72-80, 82-89, 96-100.

35 Bielski, Kronika 271; Dobrowolski T., "Geneza nagrobka Kazimierza Wielkiego w katedrze na Wawelu”, Biuletyn Historii Sztuki 37 (1975) 197-212; cf. Mrozowski, Polskie nagrobki 177-178.

36 Bielski, Kronika 386. 


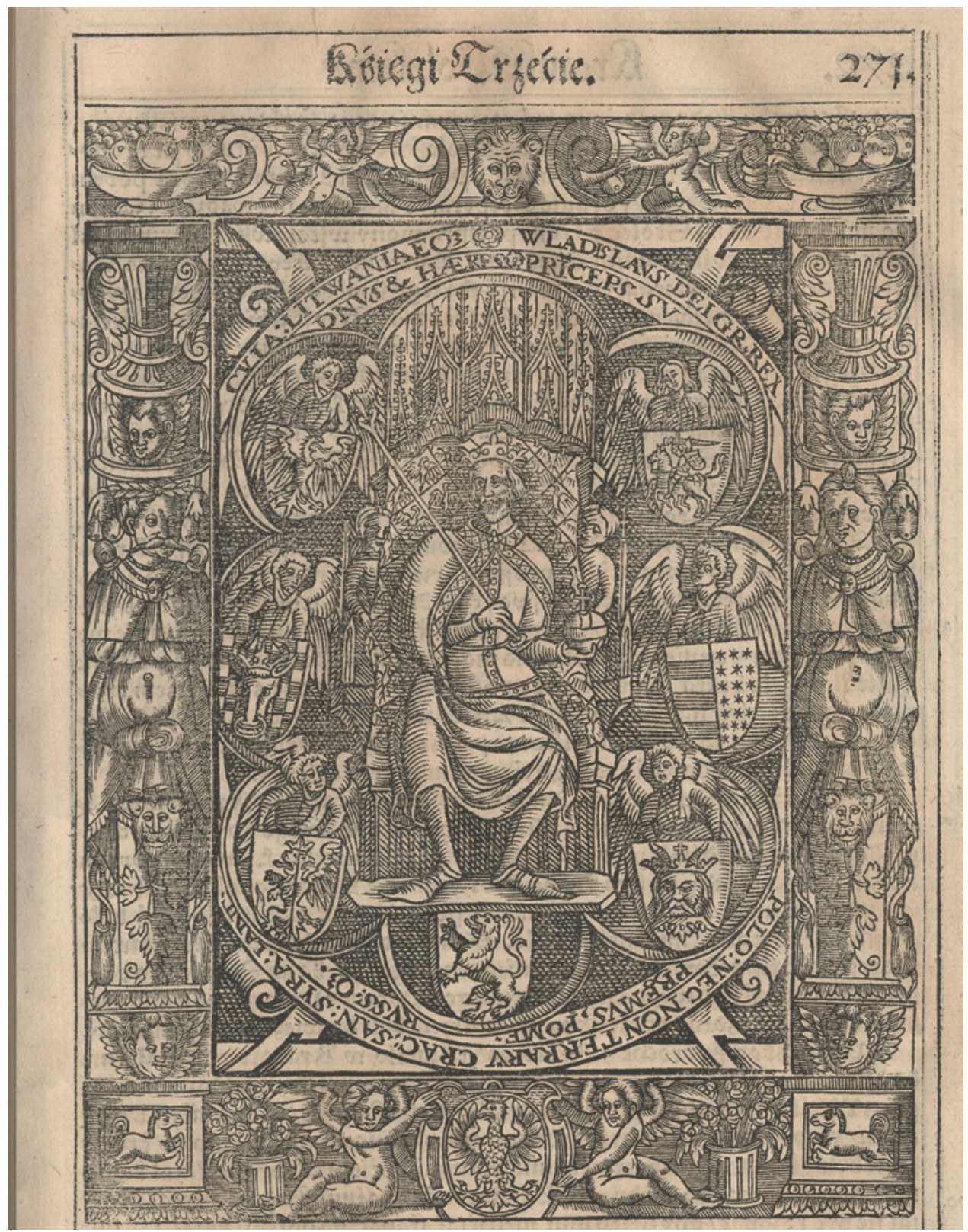

FIGURE 22.1 Representation of Władysław Jagiełło. From: Marcin Bielski, Kronika polska (ed. Joachim Bielski) (Cracow: 1597) 271 IMAGE (C) AUTHOR 
under a Gothic baldachin against a profusion of finials and traceries, just as he was represented on his great seal, ${ }^{37}$ while Kazimierz Jagiellończyk (1427-1492) [Fig. 22.2] is shown under a distinct baldacchino, with conspicuous ogival arches (not dissimilar to the ones decorating his tomb in the Wawel Cathedral). ${ }^{38}$ Clearly, a connection between these rulers and the significant objects associated with them, displaying Gothic forms, was recognized and demonstrated here, as material evidence helped to draw a distinction between legendary and historical pasts.

Although numerous great castles bore powerful witness to the aspirations of the late Piast monarchy, the attitudes toward medieval architecture were ambiguous. ${ }^{39}$ As far as many early modern commentators were concerned, the distant past was generally short on decent buildings because of the Sarmatian legacy. ${ }^{40}$ Contemporary historians, often attempting to drum up morale among the szlachta for yet another war, were keen to emphasize that the true Sarmatians did not need more than a tent over their heads, perhaps invoking the story from Tacitus, who claimed that the Sarmatians had no fixed abodes and lived in their saddles. ${ }^{41}$ Marcin Bielski's Chronicle proclaims that the

37 Bielski, Kronika 386; see Piech Z., Monety, pieczęcie i herby w systemie symboli wtadzy Jagiellonów (Warsaw: 2003) 46-48. Jaworski R., "Władca idealny w świetle alegorycznego opisu pieczęci majestatowej Władysława Jagiełły”, in Pysiak J. - Piedniądz-Skrzypczak A. Pauka M.-R. (eds.), Monarchia w średniowieczu - podstawy ideowe, władza nad ludźmi, wtadza nad terytorium. Studia ofiarowane Profesorowi Henrykowi Samsonowiczowi (Warsaw - Krakow: 2002) 321-333. See also Grzęda M., "Wizerunek Władysława Jagiełły na nagrobku w Katedrze na Wawelu", Folia Historiae Artium (new series) 13 (2015) 71-72.

38 Skubiszewska M., "Program ikonograficzny nagrobka Kazimierza Jagiellończyka w katedrze wawelskiej”, Studia do dziejów Wawelu 4 (1978) 117-214; Mrozowski, Polskie nagrobki 181-183; Węcowski P., "Pieczęć majestatowa Kazimierza Jagellończyka. Datacja oraz próba wyjaśnienia, dlaczego król przestał jej używać", Studia Źródtoznawcze 49 (2011) 97-116.

39 Guerquin B., Zamkiw Polsce (Warsaw: 1984) 7-8, 13-16.

40 These early modern stories have been corroborated by recent archaeological research on the Slavic (not Sarmatian) tribes which suggests that the 'surprising poverty of Slavic material culture' in the early Middle Ages was related to the nomadic way of life of the Slavs at the time; see Buko A., The Archaeology of Early Medieval Poland, Discoveries, Hypotheses, Interpretations (Leiden: 2008) 64-72, here 71.

41 Sarmatians were for Tacitus a nomadic tribe, without permanent settlements, and thus without knowledge of building; see Tacitus, Germania, chapter 46: 'Sarmatae live in waggons and on horseback' ('Sarmatis [...] in plaustro equoque viventibus'; ed. Henry Furneaux (Oxford: 19oo); trans. A.J. Church - W. Brodribb as Germany and Its Tribes, New York: 1942). 


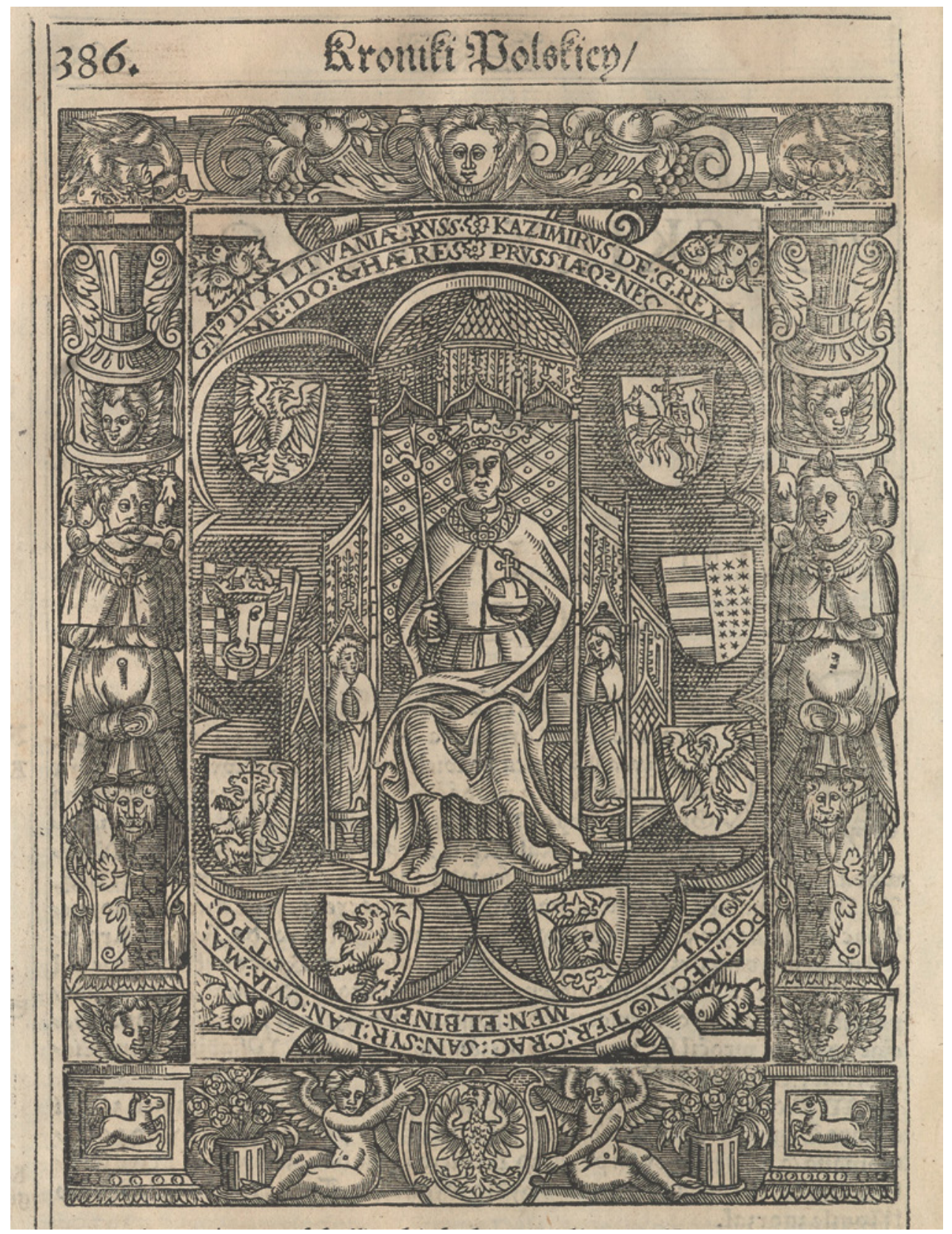

FIGURE 22.2 Representation of Kazimierz Jagiellończyk. From: Marcin Bielski, Kronika polska (ed. Joachim Bielski), (Cracow: 1597) 386

IMAGE (C) AUTHOR 
ancestors of the Polish nobility lived under their tents, not in their homes', ${ }^{42}$ and Paprocki declares that 'we are not noble because of the beauty of our houses'43 - both authors seemingly upholding this "traditional" contempt of building. Yet Starowolski, in Votum on the reform of the Commonwealth (1625), remarks on the decline of these old attitudes and derides contemporary youth, who do not want to camp in the field, finding it 'better in the chamber, because it is heated all the time. ${ }^{44}$

If the early Poles were supposed to have been content with simple abodes (if not tents), most authors agreed that the primitive forms of medieval building were replaced by new, monumental masonry architecture (especially fortifications and castles) [Fig. 22.3] under Casimir the Great, the ruler also recognized as the first law-giver. ${ }^{45}$ His reign was therefore cast as a watershed in Polish history - both solid architecture and written laws (seen together as foundations of the state) had their roots in his reign in the latter half of the fourteenth century. ${ }^{46}$ Yet the significance of this episode in history was not entirely unquestionable. Górnicki in his Dialogue embarks on a discussion of the role of Casimir the Great in the celebrated architectural revolution. ${ }^{47} \mathrm{He}$ claims (rather provocatively) that this fundamental turn in Polish history was not the accomplishment of the last Piast, who is said to have 'found Poland in wood and left it in stone', but rather the work of the 'Germans', who had settled in Poland

42 '[...] więcey pod namioty a niż doma mieszkali [...]', Bielski, Kronika, fol. 2 v. Sarmatians were not inclined to build; they were 'niebudowni', according to Bielski, Kronika 3. For a definition of this term in early modern Polish see Stownik polszczyzny XVI wieku, ed. M.R. Mayenowa, vol. XVII (Wrocław: 1987) 151.

43 'Nie zacnością kształtownych domów my zacnymi [...]', Bartosz Paprocki, Gniazdo cnoty zkąd herby rycerstwa stawnego Królestwa Polskiego, fol. <6 v >.

44 '[...] lepiey w izdebce, bo w niey palą aż do znoju [...]', Starowolski, Votum, fol. $<9 \mathrm{v}>$.

45 According to Górnicki, both written laws and masonry architecture were introduced under Casimir the Great, Górnicki, O elekcyi, wolności, fol. $<\mathrm{S} 2 \mathrm{v}>$.

46 Górnicki, $O$ elekcyi, wolności, fol. $<\mathrm{S}_{2 \mathrm{~V}}>$. On the role of Casimir the Great in the architectural 'revolution', see Crossley P., Gothic Architecture in the Reign of Casimir the Great: Church Architecture in Lesser Poland 1320-1380 (Krakow: 1985) 10-11. The list of Casimir the Great's foundations is based on a fourteenth-century chronicle by Janko of Czarnków, supplemented decades later by Jan Długosz, see Bieniak J., "Jan (Janek) z Czarnkowa. Niedokończona kronika polska z XIV wieku”, Studia Źródtoznawcze 47 (2009) 109-142; cf. Skodlarski J., "Kazimierz Wielki jako reformator i człowiek", Annales. Etyka w życiu gospodarczym 11, 1 (2008) 65-75. On Casimir the Great as a reformer of the state, see Wyrozumski J., Kazimierz Wielki (Wrocław: 2004) 188-200.

47 For a recent reassessment, see Kajzer L., "Czy historycy architektury powinni badać zamki? Uwagi na marginesie pracy Piotra A. Zaniewskiego 'Zamki Kazimierza Wielkiego”, Kwartalnik Historii Kultury Materialnej 61, 4 (2013) 632-633; cf. Zaniewski P., Zamki Kazimierza Wielkiego (Kraków: ARCo 2012) 57-78. 


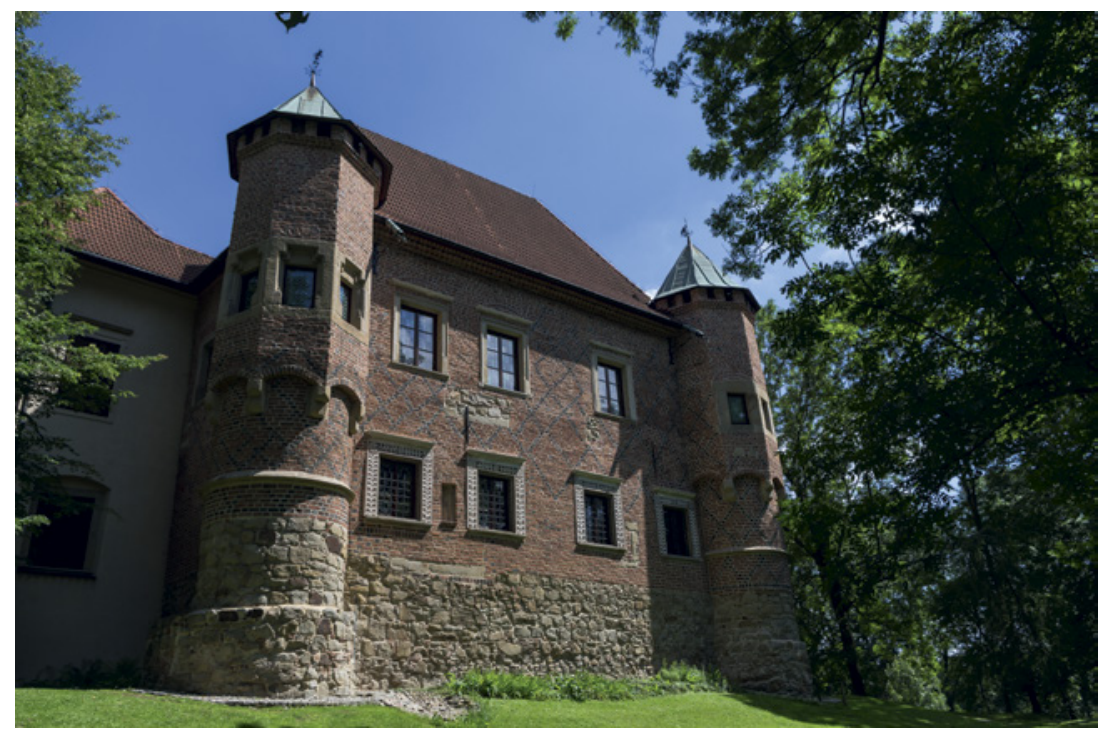

FIGURE 22.3 Dębno Castle

IMAGE (C) JOHN CIESLIK-BRIDGEN

at the time. ${ }^{48}$ Moreover, Górnicki seems to be aware of at least one important Polish patron of architecture prior to Casimir, one 'famous and celebrated Dunin of the Łabeć arms, ${ }^{49}$ a reference to Piotr Włostowic (ca. 1080-1153), the founder of several important buildings in today's Wrocław. ${ }^{50}$ According to Górnicki, Włostowic was responsible for erecting scores of ashlar churches, ${ }^{51}$ but (he adds) this was not a great accomplishment for such a large kingdom. It was the Germans, then, who turned Poland from timber to masonry, not King Casimir. To this audacious dictum (voiced in the dialogue by the Italian), the Polish interlocutor dryly responds: 'I do not know what are these cities and these walls good for', because, he argues, the Lacedaemonians had no walls at all, entrusting the safety of their state to the strength of their warriors. ${ }^{52}$

48 'A od tych Niemców za króla Kazimierza Wielkiego mury w Polszcze nastały [...] Niemcy dopiero w Polszcze mury rozmnożyli [...]', Górnicki, O elekcyi, wolności, fol. $<\mathrm{S} 2 \mathrm{v}>$.

49 '[...] on sławny y zacny Dunin herbu Łabeć [...]', Górnicki, O elekcyi, wolności, fol. $<$ S2 v $>$.

5o Świechowski Z., "Fundacje Piotra Włostowica", in Rozpędowski J. (ed.), Architektura Wroctawia, vol. 3 (Wrocław: 1997) 9-21; Skwierczyński K., "Imitatio regni. Adelige Stiftungen im Polen des 11. und 12. Jahrhunderts", in Mühle E. (ed.), Monarchische und adelige Sakralstiftungen im mittelalterlichen Polen (Berlin: 2013) 190-191.

51 'kilka abo kilkadziesiąt z ciosanego kamienia kościołów zmurował [...]', Górnicki, $O$ elekcyi, wolności, fol. $<\mathrm{S} 2 \mathrm{v}>$.

$5^{2}$ 'Y tego niewiem, co nam po tych miastach, abo po murach.' Górnicki, $O$ elekcyi, wolności, fol. $<$ S2 v $>$. 
This dialogue exposes some deeply held convictions at the heart of Polish early modern attitudes toward the ancient and medieval past. The topos of the Commonwealth sufficiently defended by the courage and skill of its warriors (and thus not needing fortifications, castles, or even cities) was repeated by numerous writers. ${ }^{53}$ By the late sixteenth century common knowledge was that the very term 'Polacy' (Poles) came from the fact that these people met their enemies in the open field (pole) to fight them, and for this reason did not need castles or fortifications (as explained by Paprocki). ${ }^{54}$ So the name of the Polish Kingdom and the nation itself was supposedly derived from a concept antithetical to architecture. Pole, a field, was the opposite of a building, just as nature is antithetical to culture. Starowolski in his Sarmatiae Bellatores alludes to this idea and gives the vitae of Casimir the Great a somewhat wry twist while praising him for taking the fortified castle of Kościan. ${ }^{55}$ The defenders were too confident of their keep, Starowolski claims, but Casimir proved that courage was more important than walls and fortifications - ironically, of course, because the king is said to have spent his lifetime building precisely such fortified castles. Here the Polish topos returns to interrogate one of the myths of Polish medieval history.

For Górnicki, this precarious defence strategy relying solely on resilience of the armed men was unwise at best. In his dialogue, the Italian protagonist alleges that because of the old chivalric tradition Poles do not know how to live in peace, or how to live well. The witty Italian (an alter ego of Górnicki himself) points out that (unlike Poles) 'all the people in the world with a sane

53 See, for instance, Kunicki, Obraz, fol. 29, or an anonymous work attributed to Feliks Kryski (1562-1618), Philopolites, to iest mitośnik oyczyzny, albo o powinności dobrego obywatela [...] (Krakow, Maciej Wirzbięta: 1688), fol. 23. On the history of fortifications in Poland, see Dybaś B., Fortece Rzeczypospolitej. Studium z dziejów budowy fortyfikacji statych $w$ państwie polsko-litewskim w XVII wieku (Toruń: 1998); Adamczyk J.L., Fortyfikacje state na polskim przedmurzu od potowy XV do końca XVII wieku (Kielce: 2004); Pilarczyk Z., Fortyfikacje state na ziemiach koronnych Rzeczypospolitej w XVII wieku (Poznań: 1997); cf. Miłobędzki A., "Budownictwo militarne miast polskich w okresie nowożytnym", Kwartalnik Historii Kultury Materialnej 26, 1 (1978) 29-30; and Majewski W. - Teodorczyk J., "Wojsko", in Wyczański A. (ed.), Polska w epoce Odrodzenia: państwo, spoteczeństwo, kultura (Warsaw: 1970) 184-196.

54 Paprocki Bartosz, Ogrod Krolewsky, w którem o początku Cesarzów Rzymskich, Arcyxiążąt Rakuskich, Królów Polskich [...] (Prague, u Daniela Siedlczańskiego: 1599) 317; the cliché of Poles fighting in the open field persisted throughout the early modern period, see Kunicki, Obraz, fol. 29; Chmielowski B., Nowe Ateny albo Akademia wszelkiey scyencyi petna, vol. 1 (Lvov: 1746) 295-296.

Starowolski S., Wojownicy Sarmaccy, trans. and ed. J. Starnawski (Warsaw: 1979) 143-144. 
mind (including the "Affricans") want the cities and the castles'. ${ }^{56}$ He then asks, rather impertinently, if Poles (who shun architecture) want to return to the wild, like the animals, to roam the forests and the bogs. ${ }^{57}$ If not, they should build more, especially in the borderlands, where new cities and castles would offer better protection against repeated Tatar incursions. ${ }^{58}$

A similar recommendation is articulated by Starowolski. He says that old Poles, when drunk, like to boast that (like their forefathers) they do not need walls, ramparts, or castles, because the best defence of the country is the chests of the Polish nobility. Alas, he continues, contemporary Sarmatians are not as fit as their ancestors, and should therefore build sufficient defences instead of measly henhouses - kurniki.59 Starowolski further develops his vision of the Middle Ages as the era of civic virtue that should inspire his contemporaries in a poem dedicated to Private Interest (1649). ${ }^{60}$ According to the author, particularisms rule in the seventeenth-century Commonwealth, as opposed to the spirit of public good that was dominant in the Middle Ages. Medieval architecture is cast here as the embodiment of this chivalric public-minded ethos of the past, whereas the contemporary szlachta, which only pays attention to its own business, is accused of investing in private houses. ${ }^{61}$ Starowolski writes of the old times: 'Look at the fortified castles, at the cities, and how many masonry monasteries can you count? How many well-founded convents, how many bishoprics, abbeys well endowed?'62 These public buildings are no longer needed, argues the author, in the country now governed by private wants. For Starowolski, this social change means a shift away from medieval public edifices towards a domination of private residences: 'I, [the author adopts here the persona of the Private Interest] do not know how to build for the public, I only know how to construct private buildings. It is because of me that the old

56 ' [...] kiedyby miasta nie były potrzebne, tedyby się w nich Niemcy, Włosi, Francuzowie, Hiszpani, Turcy, Persowie, Affrykani nie kochali [...] Co na świecie ludzi iest które sprawuie rozum, wszyscy miasta, zamki mieć chcą. Górnicki, O elekcyi, wolności, fol. $<\mathrm{S}_{3} \mathrm{r}>$. 'Czy znowu się wrócić Polacy chcecie do onego żywota zwierzęcego, gdy ludzie rozproszeni po lesiech, po błotach mieszkali [...]', Górnicki, O elekcyi, wolności, fol. $<\mathrm{S}_{3} \mathrm{r}>$.

$5^{8}$ Górnicki, $O$ elekcyi, wolności, fol. $<\mathrm{S}_{3} \mathrm{v}>$.

59 Starowolski, Votum, fol. $<12 \mathrm{v}>$.

6o Starowolski S., Prywat Polska kiervie (Krakow, Łukasz Kupisz: 1649).

61 This is, naturally, a topos taken from Pliny's Natural History (great art serves the public good, while art intended for private consumption is corrupt); see Barkan L., Unearthing the Past: Archaeology and Aesthetics in the Making of Renaissance Culture (New Haven: 1999) 68-71.

62 'Ile obronnych Zamków, ile Miast widzicie, / Y ile murowanych Klasztorów liczycie./ Ile macie Klasztorów dobrze fundowanych, Ile Biskupstw y Opactw tak hoynie nadanych' Starowolski, Prywat, fol. $<\mathrm{A}_{4} \mathrm{r}>$. 
castles are falling apart, while private palaces and manors are being erected'.63 Medieval edifices thus waste away: 'fortifications are falling, city walls are rotting, old towers are falling down, there are holes everywhere. Where are the castellated manors, apart from the old ones built by Casimir the Great, and celebrated in Poland until today? [...] Towns, castles, villages are consumed by the waters of the Vistula' ${ }^{6}$ Medieval architecture, shown to have served public good, therefore becomes the epitome of old moral order, destroyed by the new, corrupt spirit of individualism and private gain.

The symbolic importance of ancestral castles comes across very strongly in Kunicki's The Image of the Polish Nobleman. In a description of the paradigmatic nobleman, treating each part of the body in turn, the head comes first. There, we are told, virtue should preside. Significantly, she is represented in the text as occupying 'a castle', surrounded by her courtiers (justice, patience, liberality, etc). ${ }^{65}$ It is clear that there is a direct relationship between the castle and noble virtue as such - this is one of the associations (popularized in numerous sources) which partly explain the longevity of castellated architecture in Poland. ${ }^{66}$

Contrary to those interested in the symbolic significance of medieval architecture, others attempted to address critically some practical aspects of medieval building. Andrzej Frycz Modrzewski (1503-1572), leading a campaign to improve the ailing Commonwealth, noted that 'Taking care of building [...] according to our custom is delegated to officials whose duties concern other affairs' ${ }^{67} \mathrm{He}$ postulated that this reliance on non-professionals, a sign of a traditional disdain of building, should be changed to make Polish architecture sounder. ${ }^{68}$ With the same objective in mind, Frycz also lobbied for a more

63 'Bo ia dóbr pospolitych budować nie umiem/ Na prywatnych się tylko budynkach rozumiem./ Z mey przyczyny stare się Zamki obalaią/ Prywatne zaś Pałace i Dwory powstaią.' Starowolski, Prywat, fol.<A4 v>.

64 'Fortece upadaią, Miejskie gniją mury/ Dawne walą się baszty, zewsząd widać dziury./ Coć mi tu za kasztele, oprócz osad dawnych/ Od Wielkiego Kaźmirza dotąd w Polszcze sławnych/ Nowo nic nie stawiają [...] Miasta, Zamki, Osady w Wisłę powpadały [...]' Starowolski, Prywat, $<$ fol. A4 v $>$.

65 Kunicki, Obraz, fol. $<10 \mathrm{r}>$. Each of the selected parts of the body was associated with a different value (the head with virtue, eyes with Timor Dei and chastity; ears with faith and obedience, nose with prudence, and tongue with veracity).

66 Miłobędzki A., "Pałac i zamek 'renesansowy", in Jaroszewski, Renesans 411-420, here 416418; cf. Jakimowicz T., Dwór murowany w Polsce w wieku XVI (wieża - kamienica - kasztel) (Warsaw: 1979) 27-29.

67 'Doglądanie gmachów [...] wedle naszego zwyczaiu bywa poruczone tym Urzędnikom, którzy do czego inszego postanowieni są, Frycz-Modrzewski A., O poprawie Rzeczypospolitej księgi czwore (Losk: 1577), fol. 35 .

Frycz-Modrzewski A., O poprawie, fol. 35 . 
decisive shift towards fireproof masonry architecture, as he castigated the medieval tradition of building in timber. ${ }^{69} \mathrm{He}$ claimed that because of frequent fires, most houses in Poland lasted no more than 30 years, and as a remedy for this situation he proposed to his compatriots either to build out of stone or to drink less! In the West, he explained, the fires are less frequent because the people 'do not enjoy drunkenness as much'.70 Medieval building practice and traditional habits both had to be abandoned on the path to national improvement.

\section{3}

\section{Architecture}

While Polish early modern historians might have had problems locating the material remains of Sarmatian antiquity, the omnipresent medieval monuments (described simply as staroświeckie) did not attract much scholarly attention. ${ }^{71}$ Although the earliest Piast dynasty foundations of the eleventh and twelfth centuries were scarce (most of them perished because they were constructed of timber), the great medieval churches and castles of the later Middle Ages, especially those constructed under Casimir the Great (13101370), provided a vital (albeit often unacknowledged) point of reference. Ecclesiastical architecture of the Middle Ages remained a powerful source of inspiration throughout the early modern period, a situation compounded by

$69 \quad$ Frycz-Modrzewski, O poprawie, fol. $35 \mathrm{v}$.

70 ' [...] w onych krainach [...] abo ludzie z kamienia domy buduią, abo się pijaństwem nie bawią. Ale u nas gdzie mało nie wszytko budowanie drzewiane y bardzo mało iest ludzi, którziby trzeźwość miłowali, dziwna rzecz czemu tak wielka około gaszenia ognia niedbałość [...]', Frycz-Modrzewski, O poprawie, fol. 35 v.

71 See, for instance, Starowolski S., Opisanie Krolestwa Polskiego za czasow Zygmunta III (Vilnius, w Drukarni J.K.M. y Rzeczypospolitey Xx. Scholarum Piarum: 1765) 13-14, 29, or the Latin edition: Starowolski S., Simonis Starovolsci Polonia nunc denuo recognita et aucta (Wolfenbüttel, Conradi Bunonis: 1656) 8-9. Starowolski's texts are typical of the period in repeatedly using term staroświecki, 'old-fashioned' (or 'fabrica antiqua' in Latin), with reference to medieval buildings, whereas contemporary structures are described as those 'in modern fashion' ('nową architekturą wystawione' or 'recentiori architectura extructa'); see also idem, Dwor Cesarza tvreckiego i rezydencja jego w Konstantynopolu (Krakow, Franciszek Cezary: 1646) 3. For a discussion of Starowolski's architectural terminology, see Piskadło A. (ed.), Szymon Starowolski. Polska albo opisanie Położenia królestwa polskiego (Gdańsk: 200o) 28-32. On antiquarian interest in medieval architecture, see Frycz J., Restauracja i konserwacja zabytków architektury w Polsce w latach. 1795-1918 (Warsaw: 1975) 17-24; Guerquin, Zamki 7-8; and Jurkowlaniec, Epoka nowożytna 71-72. 
the inherent conservatism of contemporary building trades. ${ }^{72}$ The impact of medieval secular buildings, however, of which castles were the prime example, is more difficult to assess. ${ }^{73}$ The relative proliferation of medieval castles in the Commonwealth (undermining the Sarmatian topos of their uselessness) was a result of a relaxation of the law which had restricted the construction of fortified structures to the royalty and highest office-holders. ${ }^{74}$ By the late fourteenth century anyone with sufficient means could have built a fortified pile as the status symbol, starting with local overlords and high clergy (Ilża), down to the wealthiest knights (Smolen) $\cdot{ }^{75}$ Still, the construction of the castle entailed such an enormous financial burden that no more than 5 per cent of

72 Miłobędzki A., "Późnogotyckie typy sakralne w architekturze ziem polskich", in Białoskórski H. (ed.), Późny Gotyk. Studia nad sztuka przetomu średniowiecza i czasów nowych (Warsaw: 1965) 111-112.

73 Miłobędzki A., "Tradycja średniowieczna w polskiej rezydencji nowożytnej”, Kwartalnik Architektury i Urbanistyki 24 (1979) 339-342; idem, Architektura polska XVII wieku (Warsaw: 1980) 69; cf. Komorowski W., "Nowatorstwo i tradycjonalizm w architekturze mieszkalnej Krakowa późnego średniowiecza i wczesnej nowożytności. Zarys problematyki", Wiadomości Konserwatorskie 25 (2009) 19-27. A full discussion of Polish medieval secular architecture would exceed the limits of this paper. The literature on the subject is vast, even when restricted to residential architecture alone. For an overview of the field and further reading, see Świechowski Z., Architektura romańska w Polsce (Warsaw: 2000) 13-30; Grzybkowski A., Gotycka architektura murowana w Polsce (Warsaw: 2014) 75-83, 131-140, 157-160, 185-196, 256-265; Krassowski W., "Budownictwo i architektura w warunkach rozkwitu wielkiej własności ziemskiej (XIII w.-trzecia ćwierć XIV w.)”, in Krassowski W., Dzieje budownictwa i architektury na ziemiach Polski, 4 vols. (Warsaw: 1990), and idem, "Budownictwo i architektura w warunkach społeczeństwa stanowego (czwarta ćwierć $X I V-X V$ w.)", in Krassowski, Dzieje budownictwa 63, 280-281.

74 The earliest extant permission for a private castle is dated 1252, Kajzer, L., "Uwagi wstępne", in Bocheńska A. - Mrozowski P. (eds.), Początki murowanych zamków w Polsce do potowy XIV w. (Warsaw: 2017) 13. Under Casimir the Great, permissions were very rare, but the law was relaxed in the last decades of the fourteenth century; see Miłobędzki A., "Architektura Królestwa Polskiego w XV wieku", in Skubiszewski P. (ed.), Sztuka i ideologia XV wieku (Warsaw: 1978) 461-477; cf. Jakimowicz, Dwór murowany 28; Kajzer, "Czy historycy" 634. See also Olszacki T - Lasek P., "Zanim powstała Rzeczpospolita - zamki Królestwa Polskiego w dobie późnego średniowiecza”, КРАЯЗНАЎЧЬЯ ЗАПІСКІ 8 (2012) 66-73.

75 Jakimowicz, Dwór murowany 28 . The estimated cost of one cubic metre of the wall in the late fourteenth century was 11-25 groszy (i.e. 50 grams of silver); see Szymczak J., "Koszty murowanego budownictwa obronnego w Polsce do XVI wieku", Kwartalnik Historii Kultury Materialnej 36, 2 (1988) 233-275; idem, "Zamki i pieniądze w średniowiecznej Polsce", in Antoniewicz M. (ed.), Zamki i przestrzeń społeczna w Europie Środkowej i Wschodniej (Warsaw: 2002) 13-23. See also Lasek P., "Zamki elity monarchii Andegawenów po obu stronach Karpat. Próba wstępnej charakterystyki kastellologicznej”, in Zamkiw Karpatach (Krosno: 2014) 27-44, esp. 41; and Kołodziejski S., "Początki zamków w ziemi krakowskiej", in Bocheńska - Mrozowski, Początki murowanych 52. 
the Polish elite could have afforded the expense. ${ }^{76}$ It is estimated that the number of castles built in the second half of the fourteenth century was around $80 .{ }^{77}$ In line with the functional diversity of these structures, no single formal type of the castle developed at that time. ${ }^{78}$ However, by the late Middle Ages the fourwing complex with a corner tower (octagonal or round) dominated in terms of spatial arrangement. ${ }^{79}$ The buildings also varied according to localization (topography) and material used: brick in the northern regions of Poland and stone in the south, with more regular forms adopted in brick castles, less regular in those executed in stone. ${ }^{80}$

In the early modern period, medieval models (associated with prestige) remained critical to both large feudal seats and smaller houses of the local gentry ${ }^{81}$ Residences of the fifteenth century provide evidence of a survival of

76 The estimate provided by Kurtyka J., "Posiadłość, dziedziczność i prestiż. Badania nad późnośredniowieczną i wczesnonowożytną wielką własnością możnowładczą w Polsce XIV-XVII wieku", Roczniki Historyczne 65 (1999) 189; cf. Lasek P., Turris fortissima nomen Domini. Murowane wieże mieszkalne w Królestwie Polskim od 1300 r. do potowy XVI w. (Warsaw: 2013) 282-283.

77 Guerquin, Zamki 49. Out of this number, approximately 75 per cent were royal foundations; see Olszacki T., "Rezydencje królewskie prowincji Małopolskiej w XIV wieku możliwości interpretacji", in Architektura. Czasopismo Techniczne 108, 23 (2011) 287-289; cf. Kajzer, "Czy historycy" 634-635. The number of private castles that existed in Poland around 1500 is estimated at around 70; see Miłobędzki, "Architektura Królestwa" 463-464, and idem, "Budownictwo militarne" 30.

78 Guerquin, Zamki 26-32; Olszacki, "Rezydencje królewskie" 287-289; Olszacki and Lasek, "Zanim powstała" 67. On the diverse functions of medieval castles tied to the demands of itinerant monarchy, see Kajzer L., "Kastellologa uwagi nad itinerariami królewskimi", Światowit 1, 42 (1999) 94-98. On the early modern residences, see Jakimowicz T., "Rezydencja w Polsce w wieku XVI. Stan i potrzeby badań", Kwartalnik Architektury $i$ Urbanistyki: teoria i historia 24, 4 (1979) 311-337.

79 Guerquin, Zamki $32-38$. Concerning the spatial development of contemporary castle complexes, see Olszacki and Lasek, "Zanim powstała" 71-72. The octagonal tower (a feature inspired, perhaps, by the Teutonic Knights' architecture) has been suggested as the distinguishing mark of Casimir the Great's castles, see Zaniewski, Zamki 136-140; cf. Kajzer, "Czy historycy" 638.

8o Guerquin, Zamki 19-23, 33-34. On the importance of regularity in castle design for the royal image, see Skibiński S., "Jeszcze raz w kwestii genezy regularnego zamku krzyżackiego", in Arszyński M. (ed.), Sztuka Prus XIII-XVIII wieku (Toruń: 1994) 27-36. In addition to the dominant multi-wing arrangement, another type, with two residential piles placed across the courtyard, entered through a gate tower, was introduced in the late fourteenth century; see Miłobędzki, "Tradycja średniowieczna” 342-343; cf. Grzybkowski A., "Zamek w Rawie Mazowieckiej. Zagadnienie fundacji i genezy", Kwartalnik Architektury I Urbanistyki: teoria i historia 24, 3 (1979) 216.

81 Horbacz T. - Lechowicz Z., "Jeszcze o siedzibie rycersko-szlacheckiej w Polsce", Acta Universitatis Lodziensis. Folia Archaeologica 5 (1984) 95-96, 103-106; Lasek, Turris fortissima 176-186; Jakimowicz, Dwór murowany 27-28. The issue of changes caused by military 
the four-wing castle type, now with more regular inner courtyards and communication galleries along the wings [Fig. 22.3] (Dębno (ca. 1470-1480), ${ }^{82}$ Oporów 1434-1449), ${ }^{83}$ as well as with features that played a role that was more decorative than defensive, such as towers or prominent buttresses. ${ }^{84}$ Displays of decorative sculpture, including heraldic imagery (especially around oriel windows), complemented the image of the ancestral seat. ${ }^{85}$ This type of residence was still popular in the first half of the sixteenth century (the castle in Mokrsko built ca. $1515^{-1532 ; 86}$ or that in Szydłowiec [Fig. 22.4], rebuilt between 1509 and 1532). ${ }^{87}$ At the same time, some large medieval residences were modernized, gaining formal features rooted in the past to enhance their antiquated appearance. Ciechanów Castle (ca. 1380-1430) [Fig. 22.5], for instance, was rebuilt after 1549 for Bona Sforza, in a way which underscored its medieval characteristics, such as the towers, which were heightened, contrary to contemporary

developments in the early modern period is discussed by Guerquin, Zamki $57-58$. On castles as status symbols in the early modern period, see Olejnik K., "Zamek w strukturach politycznych i militarnych państwa szlacheckiego", in Antoniewicz, Zamki i przestrzeń 216-227.

82 Lasek, Turris fortissima 171, 176; Chrzanowski T. - Kornecki M., Sztuka Ziemi Krakowskiej (Krakow: 1982) 76-78; Dębno was was built for Crown Chancellor Jakub Dębiński (14271490); see Guerquin, Zamki 141-143.

83 Oporów was a residence of Władysław Oporowski (1395-1453), archbishop of Gniezno, primate of Poland, and deputy chancellor; see Gąsiorowski A., "Oporowski Władysław", Polski Stownik Biograficzny, vol. 24 (Wrocław: 1979) 142-144. On Oporów Castle, see Bocheński Z., "Dwór obronny arcybiskupa Władysława Oporowskiego (zm. 1453) w Oporowie pod Kutnem", Biuletyn Historji Sztuki i Kultury: kwartalnik wydawany przez Zaktad Architektury Polskiej i Historji Sztuki Politechniki Warszawskiej 3 (1933) 127-131; Lasek, Turris fortissima 153-154.

84 Guerquin, Zamki 56; Lasek, Turris fortissima 236.

85 Gryglewski P., "Przestrzeń, fundator, budowla. Struktura regionalna w badaniach nad rekonstrukcją krajobrazu architektonicznego", Acta Universitatis Lodziensis. Folia Sociologica 37 (2011) 77, 79-80; Kuczyński S.K., "Człowiek wobec świata herbów", in Michałowski R. (ed.), Cztowiek w spoteczeństwie średniowiecznym, (Warsaw: 1997) 332; Lasek, Turris fortissima $245^{-252}$.

86 Concerning castle in Mokrsko, built for Crown Marshall Piotr Kmita (1477-1553), see Miłobędzki A., "Zamek w Mokrsku Górnym i niektóre problemy małopolskiej architektury XV i XVI wieku", Biuletyn Historii Sztuki 21 (1959) 222-233.

87 For Szydłowiec, constructed for Stanisław Szydłowiecki (1405-1494), Crown Court Marshal, see Puget W., "Z dziejów zamku w Szydłowcu", RocznikMuzeum Świętokrzyskiego 4 (1967) 261-302; Brykowska M., "Fundacje Szydłowieckich - między gotykiem a renesansem", in Iwańczak W. - Kubicki R. (eds.), Fundacje kanclerza Krzysztofa Szydtowieckiego. $Z$ dziejów budownictwa rezydencjonalno-obronnego na terenie dawnego województwa sandomierskiego (Kielce - Ćmielów: 2011) 29-48. 


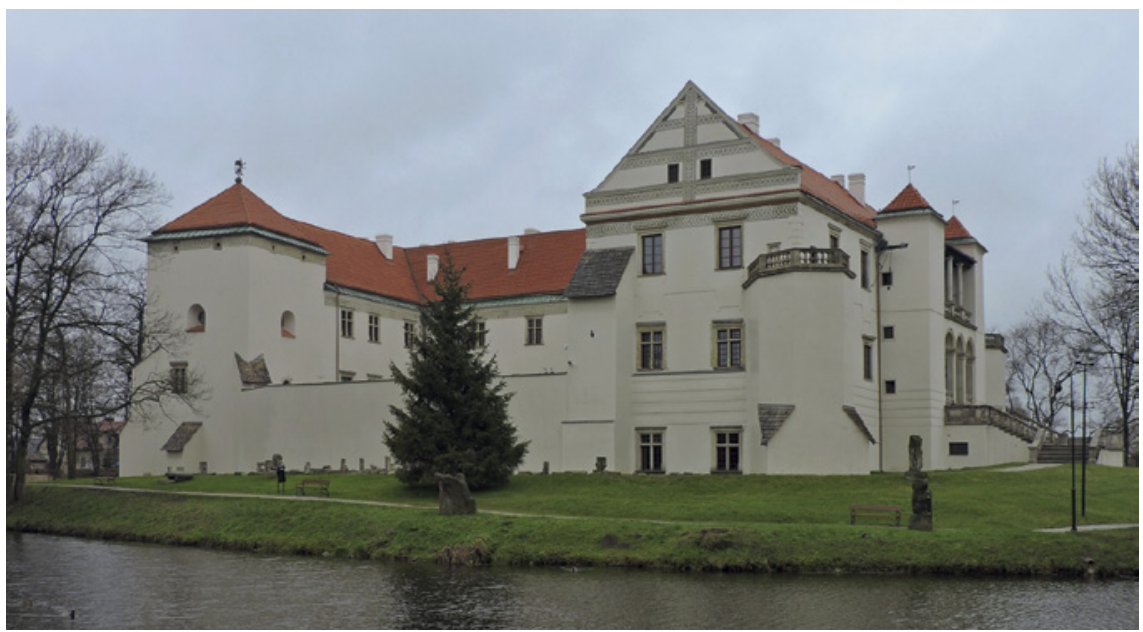

FIGURE 22.4 Szydłowiec Castle

IMAGE (C) VISUAL ARCHIVE, INSTITUTE OF ART HISTORY, UNIVERSITY OF WARSAW

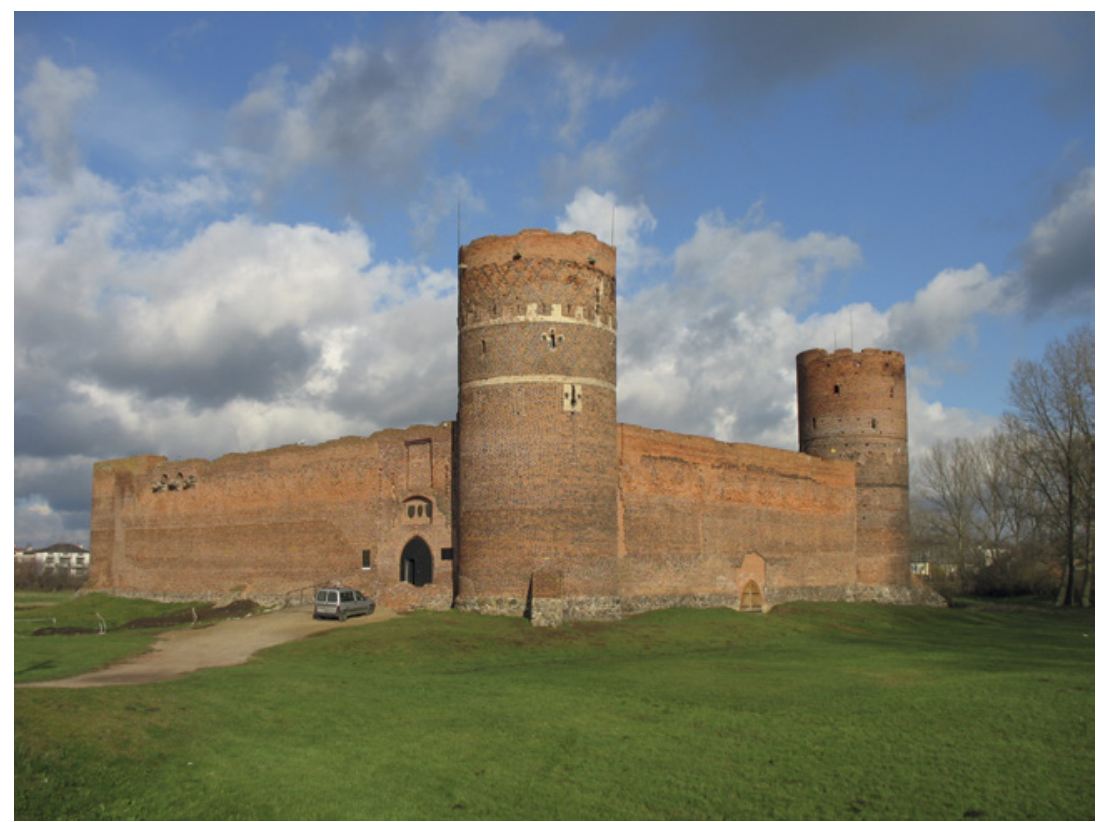

FIGURE 22.5 Ciechanów Castle

IMAGE (C) VISUAL ARCHIVE, INSTITUTE OF ART HISTORY, UNIVERSITY OF WARSAW 


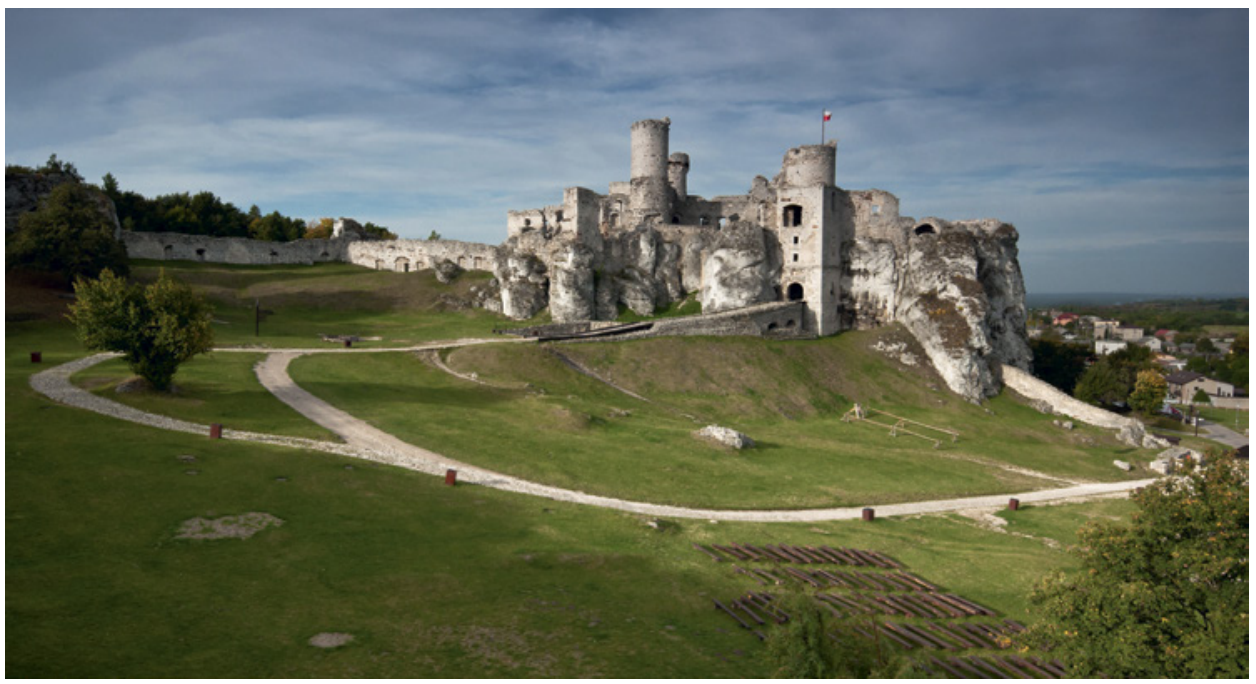

FIGURE 22.6 Ogrodzieniec Castle

IMAGE (C) ŁUKASZ ŚMIGASIEWICZ

military requirements, ${ }^{88}$ while the old residential quarters were expanded, providing more comfort.

It has been noted that pseudo-feudal residences in the sixteenth century were generally erected by upwardly mobile office holders or high clergy, not the really old aristocracy. ${ }^{89}$ The invented past was, of course, a means of legitimation (as in the visual equivalents of the genealogies penned by Paprocki). The best examples are Ogrodzieniec [Fig. 22.6], rebuilt for the Boner family (merchants, royal bankers, and salt mine managers); ${ }^{90}$ Bodzentyn for Franciszek

88 In the sixteenth century most towers were lowered because of exposure to artillery fire; see Guerquin, Zamki 58 . Similar modernization (enhancing the towers) was undertaken for Bona Sforza in Czersk Castle, see Kunkel R., "Typologia średniowiecznych zamków książęcych i możnowładczych na Mazowszu", Kronika Zamkowa 53-54 (2007) 211-212, 213-214, 221.

89 Jakimowicz, Dwór murowany 23-26; Bogucka M., "Miasto i mieszczanin w społeczeństwie Polski nowożytnej (XVI-XVIII wiek)", Czasy nowożytne 22 (2009) 38-39; Miłobędzki, "Pałac i zamek" 413-415; Guerquin, Zamki 59; cf. Jakimowicz T., "Dom pański jako ma być postawion", in Jaroszewski, Renesans 423; Wyrobisz A., "Architektura w służbie społecznej i politycznej w Polsce XVI-XVIII wieku”, in Bania Z. (ed.), Podtug Nieba i zwyczaju polskiego. Studia z historii architektury, sztuki i kultury ofiarowane Adamowi Mitobędzkiemu (Warsaw: 1988) 524-525.

$90 \quad$ Regarding the Boner family, see Ptaśnik J., "Bonerowie”, Rocznik Krakowski 7 (1905) 1-134; Hanik M., Trzy pokolenia z rodziny Bonerów (Krakow: 1985) passim; Kaussler E., Ein Pfälzer in Polen. Die Landauer Boner und ihre Weißenburger Freunde (Neustadt/Weinstraße: 1974) 


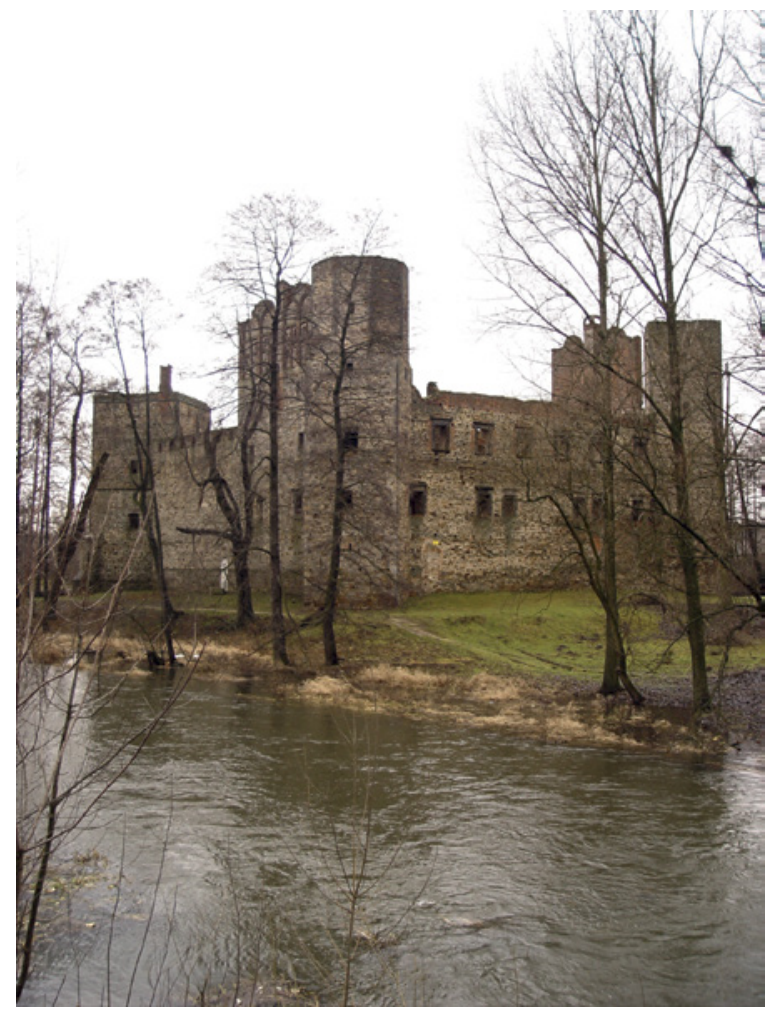

FIGURE 22.7

Drzewica Castle

IMAGE (C) JAROSŁAW KRUK

Krasiński (1525-1577), the secretary of King Sigismund Augustus and the bishop of Krakow; ${ }^{91}$ or Drzewica (1527-1535) [Fig. 22.7], for Maciej Drzewicki (14671535), the crown chancellor, archbishop of Gniezno, and primate of Poland..$^{92}$ Lesser gentry, meanwhile, around 1500 adopted in their residences a number of

passim. The Boners were involved in the construction of Wawel Castle, as well as the main state fortress, the castle of Kamieniec Podolski; see Mossakowski S., Rezydencja królewska na Wawelu w czasach Zygmunta Starego. Program użytkowy i ceremonialny (Warsaw: 2013) 113-122; Torbus T., "Architektura siedzib Zygmunta Starego jako wyraz dbałości o wizerunek dynastii”, in Mrozowski - Tyszka - Węcowski, Europa Jagiellonica 1386-1572 188-189.

91 On the founder, see Nitecki P., Biskupi kościoła w Polsce w latach 965-1999. Stownik biograficzny (Warsaw: 2000) 225-226; regarding the castle, see Brykowska M., "Zamek/pałac biskupów krakowskich w Bodzentynie Przemiany zespołu i architektury w okresie XIVXVIII wieku", in Kajzer L. (ed.), Siedziby biskupów krakowskich na terenie dawnego województwa sandomierskiego (Kielce: 1997) 41-55.

92 Regarding the patron, see Rybus H., "Prymas Maciej Drzewiecki: zarys biografii (14671535)", Studia Theologica Varsaviensia 2 (1964) 79-308. On the castle, see Guerquin B., "Zamek w Drzewicy", Teka Konserwatorska 1 (1952) 5-17. 


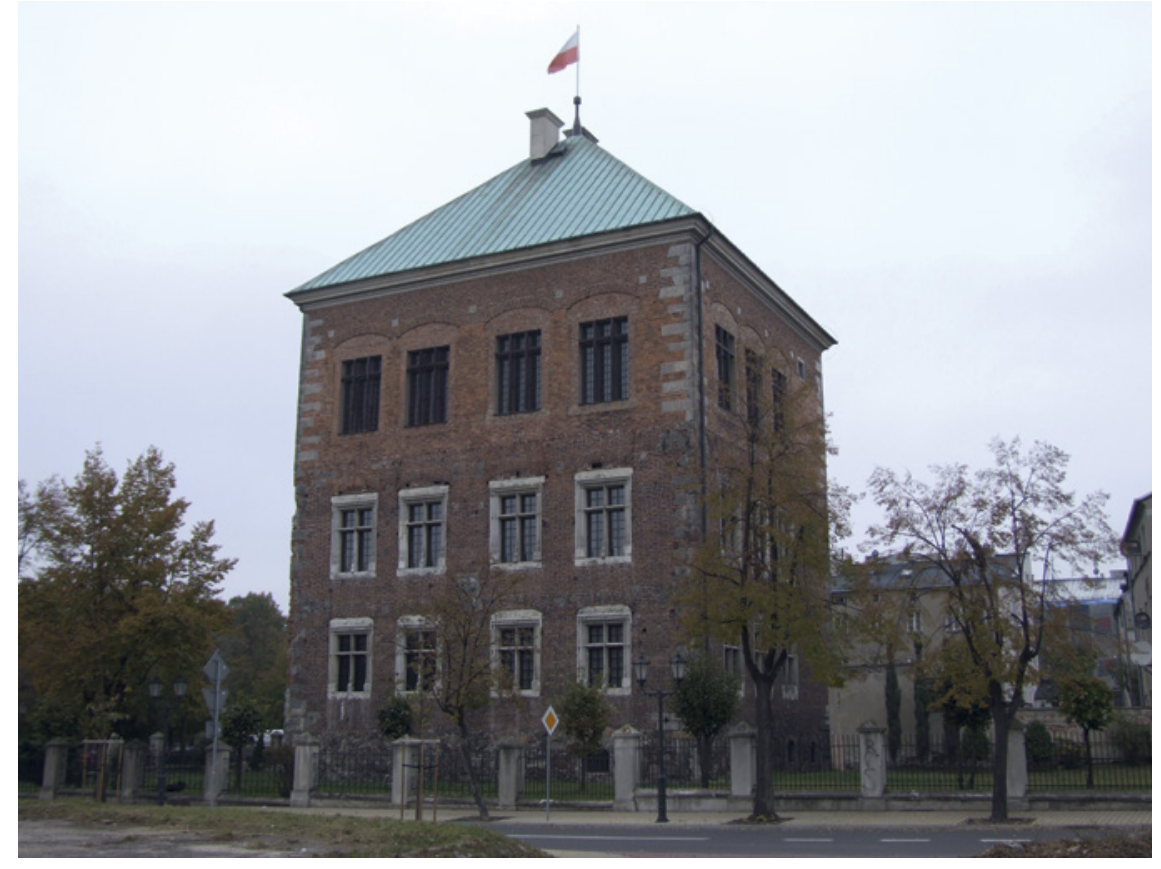

FIGURE 22.8 Royal Castle in Piotrków

IMAGE C JERZY STRZELECKI

spatial solutions refining medieval pattern of the residential tower. ${ }^{93}$ Its roots, deep in the medieval donjons and their diverse derivations, were updated in line with the expectations of the early modern owners. ${ }^{94}$ The royal castle in Piotrków [Fig. 22.8] provided the point of reference for these seats of varied functional and formal arrangements. ${ }^{95}$ They have been divided into proper

93 See Jakimowicz, Dwór murowany 22-43; for a more recent discussion, see Lasek, Turris fortissima 191-198; idem, "Zagadnienie tzw. dworów wieżowych. Przyczynek do badań nad późnośredniowiecznym budownictwem obronno-rezydencjonalnym", in Czyż A.S. (ed.), Architektura znaczeń. Studia ofiarowane prof. Zbigniewowi Bani w 65 rocznicę urodzin i w 40-lecie pracy dydaktycznej (Warsaw: 2011) 30-39.

94 Lasek P., "Nowa moda czy kontynuacja? Murowane wieże mieszkalne w Królestwie Polskim na przełomie średniowiecza i epoki nowożytnej", in Rolska-Boruch I. (ed.), Studia nad sztuka Renesansu i Baroku. Programy ideowe w przedsięwzięciach artystycznych w XVI-XVIII wieku (Lublin: 2010) 499-508; idem, "Obronno-mieszkalne czy mieszkalnoobronne? Cechy mieszkalne, reprezentacyjne i obronne rezydencji wieżowych elity feudalnej Królestwa Polskiego", in Badowska K. - Wasiak W. - Łuczak P. (eds.), Broń i wojna w dziejach człowieka (Łódź: 2009) 167-176.

95 On Piotrków Castle, see Jakimowicz T., "Turris Pyothrkoviensis - pałac Zygmunta I", Kwartalnik Architektury i Urbanistyki 17 (1972) 21-38; Rutkowski H., "Zamek w Piotrkowie", 


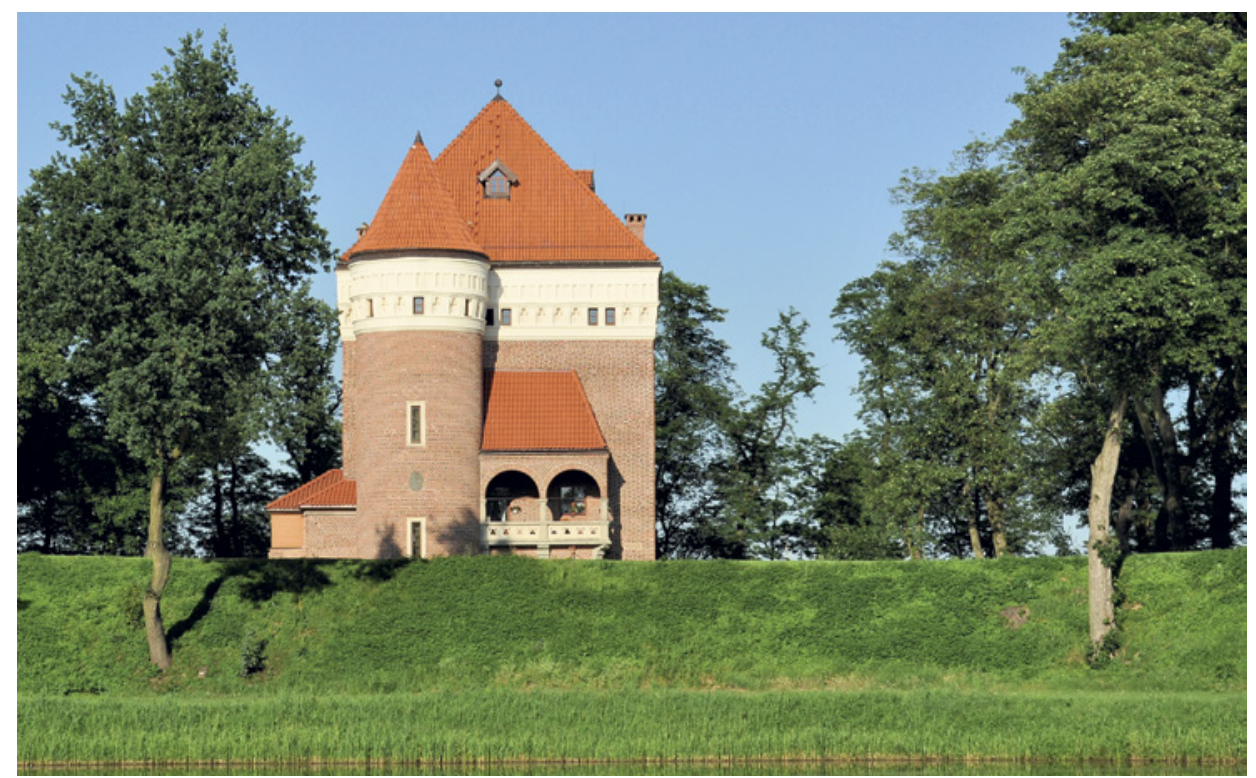

FIGURE 22.9 Residential tower in Rzemień IMAGE (C) KROTON

towers (wieże) (Szamotuły, Wojciechów, and Rzemień [Fig. 22.9]); two-storey tower houses (kamienice) (Jeżów and Jakubowice); and castelli (kasztele), perhaps of Hungarian provenance ${ }^{96}$ (Szymbark ca. 1550-160o [Fig. 22.10] and Pabianice $\left.15^{6} 5^{-1571}\right) .{ }^{97}$ The symbolic value of the tower, which had since the Middle Ages been nearly synonymous with a ruler's seat (needed for representation) is unquestionable, but in the Polish context this model also had some practical advantages: a simple pile on a compact plan was cheap, and its fortified character was useful (just in case). ${ }^{98}$ The popularity of this medieval house

Kwartalnik Architektury $i$ Urbanistyki 3, 2 (1958) 155-176. Part of the royal Wawel Castle - the Kurza Noga - was also a tower residence; see Fischinger A., "Czym była kurza noga w zamku królewskim na Wawelu”, Rocznik Krakowski 55 (1989) 76-87; cf. Ratajczak T., "Podróże władcy i architektura. Przebudowa królewskich rezydencji za panowania Zygmunta Starego", Artium Quaestiones 17 (2006) 5-37, here 12.

96 For details, see Jakimowicz, Dwór murowany 141-149.

97 For details, see Jakimowicz, Dwór murowany 91 ff.; cf. Lasek, "Zagadnienie tzw. dworów wieżowych" $30-33$.

98 Jakimowicz, Dwór murowany 69-71; Lasek, Turris fortissima 277-281; Meyer W., "Die Burg als repräsentatives Statussymbol. Ein Beitrag zum Verständnis des mittelalterlichen Burgenbaus", Zeitschrift für schweizerische Archäologie und Kunstgeschichte 33 (1976) 175179; cf. Jakimowicz T., “Sibi et posteritate'. Treści ideowe rezydencji feudalnej w Polsce 


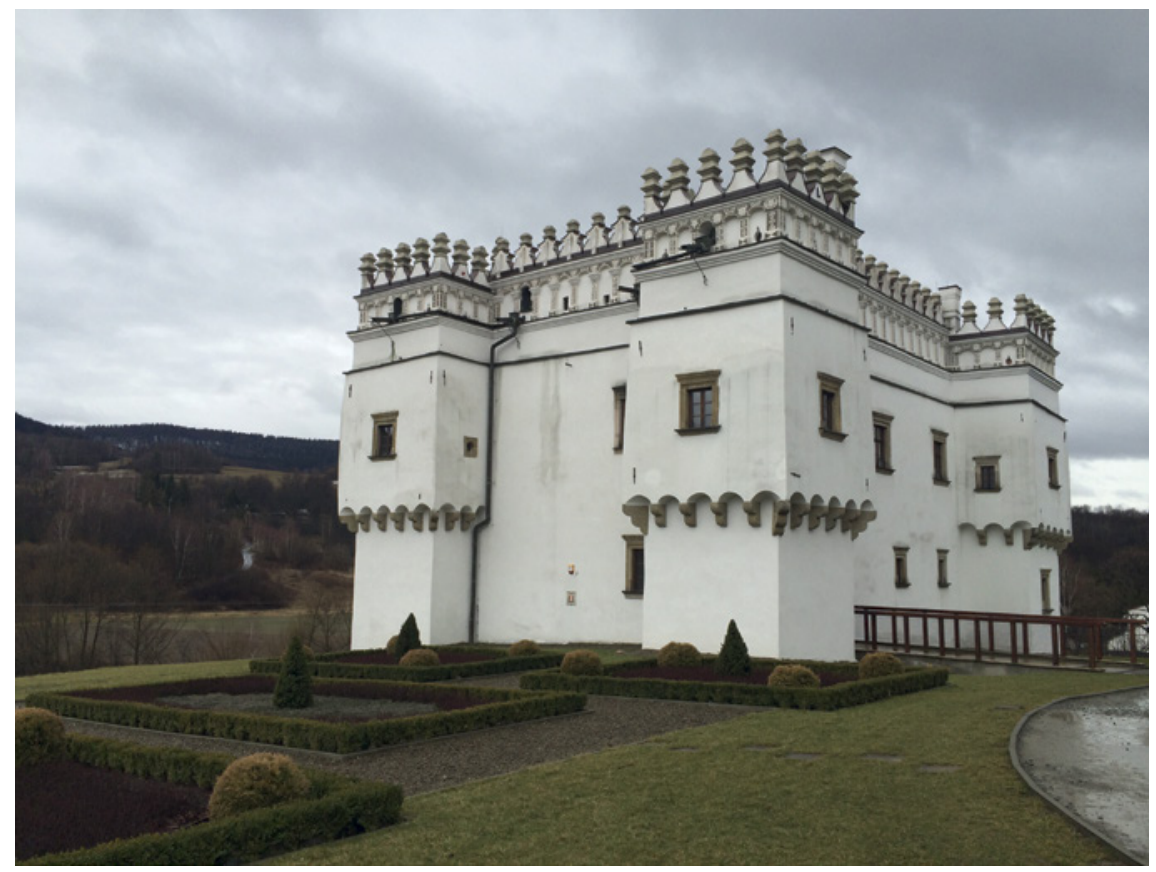

FIGURE 22.10 Kasztel in Szymbark

IMAGE (C) MAREK ARCISZEWSKI

type ends around 1580 , when the compact house of Italian origin, as in Książ Wielki, replaces this older type. ${ }^{99}$

Not all sixteenth-century residences, however, implemented this new compact model. Many, for reasons shown above, utilized the time-sanctioned fourwing arrangement, replacing old towers with bastei towers, which responded in form to the dangers of artillery fire, and which also often received new forms of crenellations in the form of the so-called Polish attic. ${ }^{100}$ Among numerous

XVI-XIX w.", in Opaliński E. - Wiślicz T. (eds.), Rezydencje $w$ średniowieczu i czasach nowożytnych (Warsaw: 2001) 252-267.

99 Miłobędzki, Architektura polska 69-70, 72-73; cf. idem, "Zamek w Pińczowie za Myszkowskich. U początków nowożytnej rezydencji w Polsce", in Białostocki J. (ed.) Sarmatia artistica. Ksiega pamiątkowa ku czci profesora Wtadyslawa Tomkiewicza (Warsaw: 1968) 35-42.

100 Bogdanowski J., "Z badań nad zależnościami pomiędzy zastosowaniem broni palnej i architekturą małopolskich zamków obronnych (XV-XVI w.)", Sprawozdania Polskiej Akademii Nauk, Oddziat w Krakowie 11 (1967) 839 f.; Lasek P., "Wieża i basteja. Z badań nad wpływem broni palnej na architekturę obronno-rezydencjonalną Królestwa Polskiego w XVI-XVI w.", Studia i Materiaty Archeologiczne. Interdyscyplinarne badania zatożeń rezydencjonalnych i obronnych 2 (2013) 158-175; on the Polish attics, see Arciszewska B., 
examples is Krasiczyn (ca. 1550-1620), planned around an ample rectangular court. ${ }^{101}$ The emphasis here was on genealogy and class pride, with four corner towers given names reflecting the Sarmatian view of Polish society, with the Divine tower containing the chapel, complemented by the Papal, Royal, and Noble towers. ${ }^{102}$ A similar layout was used in Ossolin where, rather late, in 1633, the ambitious Chancellor Jerzy Ossoliński (1595-1650) built a castle to legitimize his spectacular rise in the ranks. ${ }^{103}$ Having received the princely title from the pope and the emperor in the very same year (1633), Ossoliński embarked on a building campaign with an aim to construct a residence in the old-fashioned' (read: medieval) way, built 'practically for eternity'104 (alas, the castle was blown up in 1816 by subsequent owners). ${ }^{105}$ The castellated architecture clearly served to back the claim to a higher social position.

Krzysztof Ossoliński (1587-1645), the older half-brother of Jerzy and from 1638 the Sandomierz woivode, also chose to demonstrate his social ascent by erecting a residence that still stands as a great testimony to the attraction of medieval, chivalric architecture - Castle Krzyżtopór in Ujazd. ${ }^{106}$ Ossoliński,

"The 'Polish roof' and 'the Polish attic' in architectural history of early modern Poland", in Chatenet M. - Gady A (eds.), Toits d'Europe, Formes, structures, décors, identités, usages du toit à l'âge moderne (XVe, XVI ${ }^{e}, X V I I^{e}$ siècles) (Paris: 2016) 153-172.

101 The Krasiczyn residence was expanded for Stanisław Krasicki (1540-1602) and his son Marcin Krasicki (1574-1631); see Frazik J., "Zamek w Krasiczynie", Zeszyty naukowe Politechnika Krakowska 12 (1968) 156-180; Zlat M., "Zamek w Krasiczynie”, Studia Renesansowe 3 (1963) 5-149; Proksa M., "Zamki w Południowo-wschodniej Polsce w świetle badań archeologiczno-architektonicznych i źródeł pisanych", Rocznik HistorycznoArchiwalny 7-8 (1994) 12-13; Guerquin, Zamki 183-184.

102 Świechowski Z. - Świechowska E. - Zlat M., Sztuka polska:Renesans i Manieryzm (Warsaw: 2004) 270; Kozakiewiczowie H. and S., Renesans w Polsce (Warsaw: 1976) 203-204.

103 For Ossoliński's biography, see Bohomolec F., Życie J. Ossolińskiego, Kanclerza Wielkiego Koronnego, lubelskiego, lubomelskiego, lubaczowskiego, bohusławskiego, brodnickiego, ryckiego, derpskiego, adzielskiego, stanistawowskiego i bydgoskiego, starosty (Leipzig: 1838); and Ossoliński J., Pamiętniki, ed. W. Czapliński (Warsaw: 1976).

104 '[...] z staroświecka murów grubo, prawie na wieczność murowany [...]', from an entry in a 1755 inventory, after Sobieszczański F.M., Wiadomości historyczne o sztukach pięknych w dawnej Polsce (Warsaw, S. Orgelbrand: 1849) 161-162. On one of the gates of Ossolin (according to the same 1755 inventory) there was a marble plaque with a Latin inscription commemorating the founding of the House in 1380; Sobieszczański, Wiadomości 161.

105 On Krzysztof and Jerzy Ossoliński and their patronage, see Chrościcki, Sztuka i polityka 114-118; Miłobędzki, Architektura polska 207-216. The imperial and papal honours were, significantly, annulled by the Polish sejm in 1638; Bohomolec, Życie 257 and 303. On Ossolin Castle, see Guerquin, Zamki $245^{-246 .}$

106 For the most recent comprehensive analysis of the Krzyżtopór residence, see Kuls T., Krzyżtopór (Warsaw: 2014). 
who was a well-educated and well-travelled man, ${ }^{107}$ most likely provided a design of his own invention. ${ }^{108}$ Often compared to Caprarola, the seat was in fact an apex of a long tradition of Polish castles, a palazzo in fortezza set within a system of novel bastion fortifications. ${ }^{109}$ Although they are not as effective as they may seem, Ossoliński (who saw combat against the Turks in 1612 and financed a detachment of husaria cavalry) might have treated the defensive function as important, hence the gigantic scale and impressive fortifications exploiting the opportune location and a natural source of water within the walls. His residence, however, had all the hallmarks of modernity, even luxury, which was at odds with its consciously pseudo-medieval programme, driven by the obsessive theme of a family past seen as a vital part of more universal history, indeed cosmic in its scope (hence 4 towers, 12 halls, 52 chambers, and 365 windows). ${ }^{110}$ The heraldic note is present right at the entrance [Fig. 22.11], with the armorial Cross (Krzyz) and Axe (Topór) referring to the family coat of arms. ${ }^{111}$ At the centre of the programme was the amazing gallery of ancestors [Fig. 22.12], allies, and exempla of noble ethics, elucidated by suitable mottoes and epigrams. The images were not executed al fresco, but must have been painted on cloth or wood and mounted on the elevation of the courtyard, whereas the verses were executed in fresh plaster. ${ }^{112}$ The rationale for this gallery was a feudal concept of status derived from blood (as seen in Paprocki), the sense of self-importance provoked by the enormous success of Krzysztof's younger half-brother, Jerzy, as well as prestige of Krzysztof's wife's family, the Firlejs, who had a number of extravagant residences in eastern Poland, including Janowiec [Fig. 22.13], an imposing rendition of a medieval castle. ${ }^{113}$

107 Broniarczyk M., "Wykształcenie świeckich senatorów w Koronie za Władysława IV", Kwartalnik Historyczny 119 (2012) 263-264.

108 Cf. Meyer N., "Krzyżtopór - der Herrscher als Festung. Eine anthropomorphe Deutung der Residenz des Krzysztof Ossoliński in Ujazd”, Biuletyn Historii Sztuki 55 (1993) 467-481.

109 Fabiański M., "O genezie architektury pałacu Krzyżtopór w Ujeździe i jego dekoracji", Biuletyn Historii Sztuki 58 (1996) 269-278; Mossakowski S., "Krzyżtopór a Caprarola", in Mossakowski S. (ed.), Orbis Polonus. Studia z historii sztuki XVII-XVIII wieku (Warsaw: 2002) 25-30. On fortifications, see Guerquin, Zamki 314-316. The building was roughly completed in 1644, a year before the founder's death (1645). It became a wedding gift to Ossoliński's only son, Krzysztof Baldwin, during a ceremony attended by King Władysław IV.

110 Chrościcki, Sztuka i polityka 117-118.

111 The Axe (Topór) is the Ossolińskis' crest, while the Cross refers to 'Dębno', Ossoliński's mother's coat of arms. There was reportedly a now missing inscription next to the gate: 'The Cross is the defence, the Cross is the support, the Children, of our Axe' ('Krzyż obrona, krzyż podpora, Dziatki naszego Topora'); see Kuls, Krzyżtopór 18.

112 Kuls, Krzyżtopór 44-49.

113 See Jusiak P., "Elementy prestiżu społecznego w działalności rodziny Firlejów w XVI wieku", Socium 8 (2008) $45^{-55}$, here $47^{-51}$. The founder of the family fortune, Piotr 


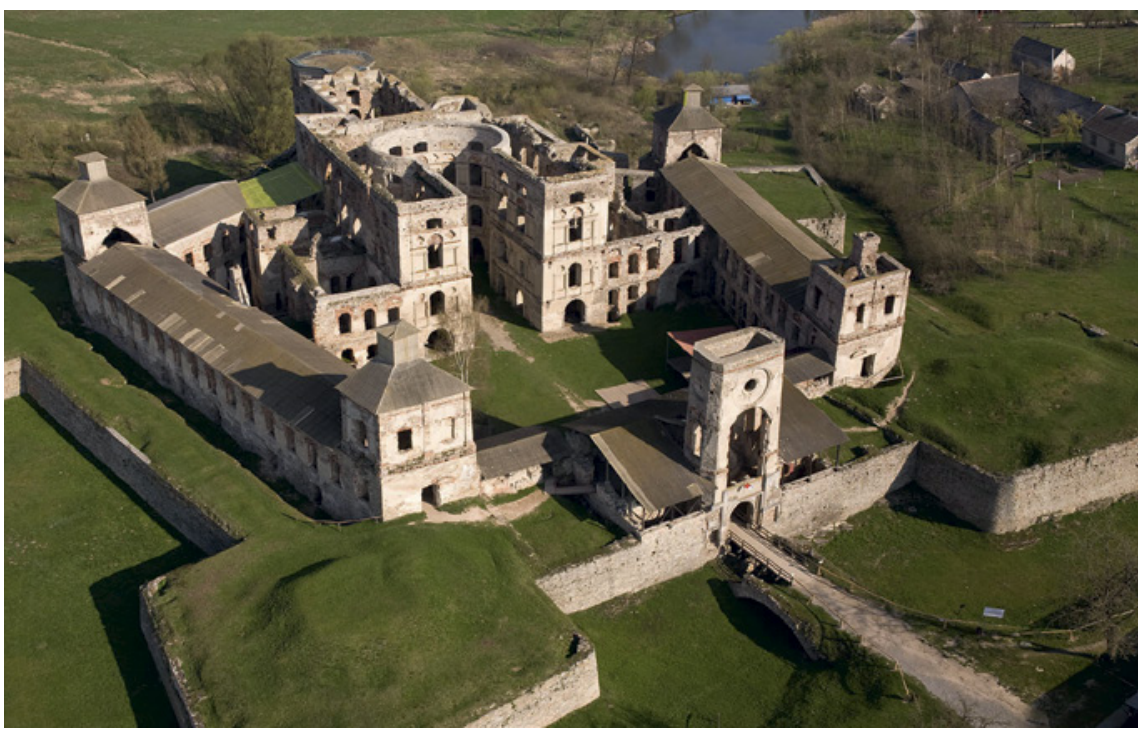

FIGURE 22.11 Castle Krzyżtopór in Ujazd IMAGE (C) VISUAL ARCHIVE, INSTITUTE OF ART HISTORY, UNIVERSITY OF WARSAW

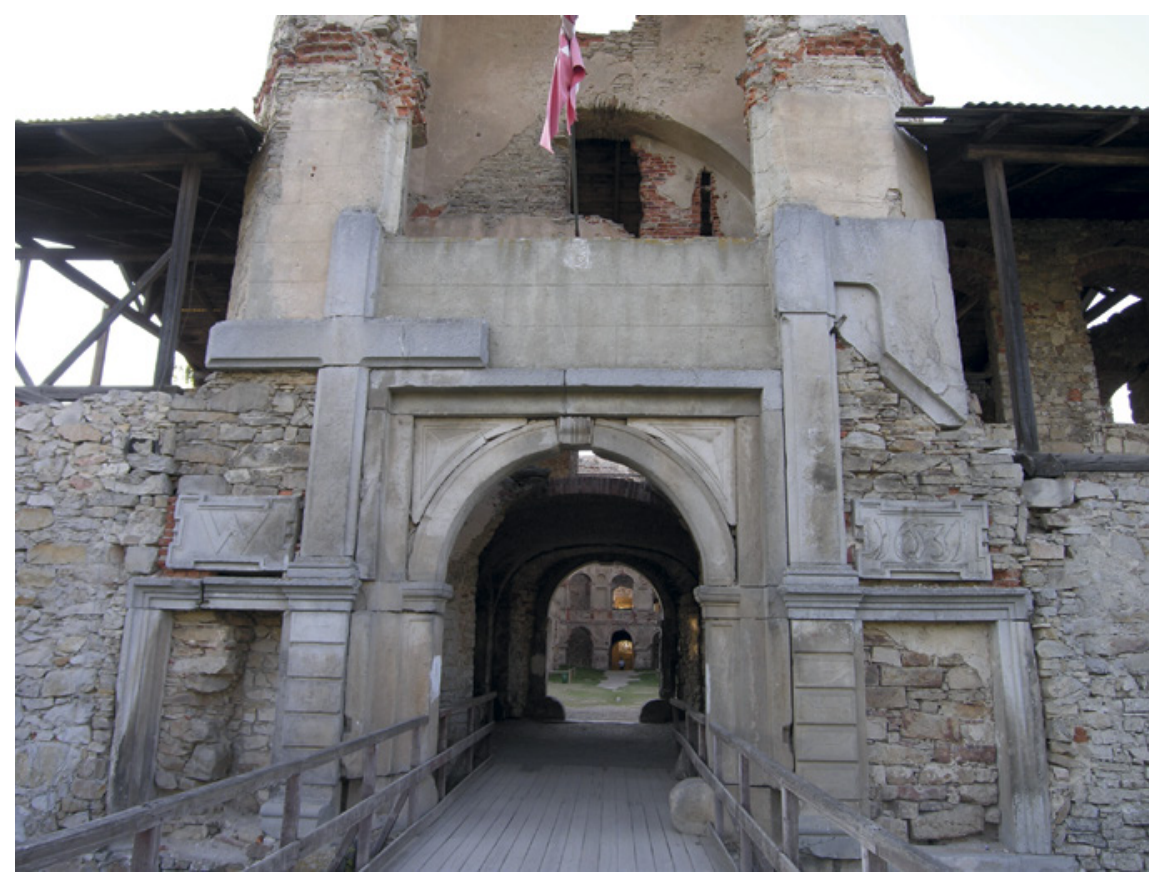

FIGURE 22.12 The gate house of Castle Krzyżtopór in Ujazd IMAGE (C) MAREK ARCISZEWSKI 


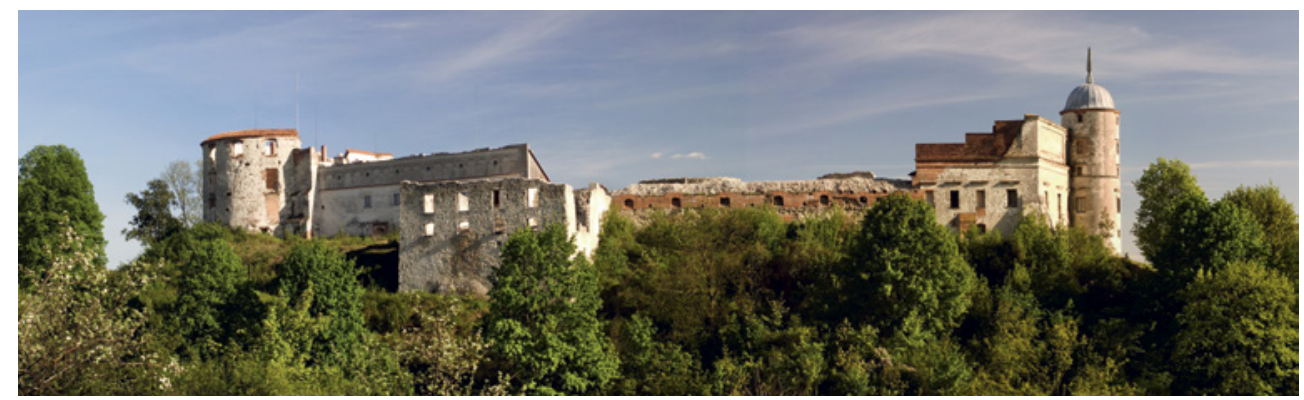

FIGURE 22.13 Firlej Castle in Janowiec

IMAGE (C) SEMU

The foolhardy tendency to build castles continued, however, ruining many fortunes - notable examples are Zbaraż, for Krzysztof Zbaraski (built in the 1620s), ${ }^{114}$ or Wiśnicz Nowy (1615-1621) and Łańcut (1629-1641), for Stanisław Lubomirski ${ }^{115}$ - so much so that by the 1650 , the anonymous author of the Brief Study of the Construction of Manor Houses felt compelled to address the issue. ${ }^{116} \mathrm{He}$ advised strongly against the construction of castles as being costly,

Firlej, started with transforming the family manor in Dąbrowica into a castle; see Rolska-Boruch I., 'Domy Pańskie' na Lubelszczyźnie od późnego gotyku do wczesnego baroku (Lublin: 2003) 117-119. On Janowiec, see Kurzątkowska A., Mecenat artystyczny Firlejów (1526-1626), Dissertation (Warsaw: 1963) 70-71; Rolska-Boruch, Domy Pańskie 128-129. Supryn M., Archeologia zamku w Janowcu (Kazimierz Dolny: 2008) 50-73.

114 Arciszewska B., "Vicenzo Scamozzi and modernization of architecture in PolishLithuanian Commonwealth", in Barbieri F. - Avagnina M.E. - Sanvito P. (eds.), Vincenzo Scamozzi Teoretico Europeo (Vicenza: 2016) 235-239.

115 Miłobędzki, Architektura polska 169-174; cf. Andrzejewski A. - Kajzer L., "Modernizations of Medieval Castles and the Problem of 'palazzo in fortezza' in Great Poland in the 15th${ }_{17}$ th Centuries", in Caune A. - Ose I. (eds.), Castella Maris Baltici (Riga: 2007) 9-18; Kajzer L., "Z problematyki badań założeń typu palazzo in fortezza w Polsce", in Czyż, Architektura znaczeń 66-67; On the early modern modernizations of medieval castles, see Wasik B., "Zamki pokrzyżackie w województwie chełmińskim w czasach Rzeczypospolitej Obojga Narodów", Wiadomości Konserwatorskie 41 (2015) 20-35, 31-32. Castellated architecture continued to be an inspiration as late as the eighteenth century, especially in the eastern borderlands (e.g. Ołyka of the Radziwiłł family, Korzec of the Czartoryski, Warkowicze of the Ledóchowski); see Kowalczyk J., "Rezydencje późnobarokowe na Wołyniu”, Przegląd Wschodni 4 (1997) 25-73; cf. Miłobędzki A., "Architektoniczna tradycja średniowiecza w krajobrazie kulturowym Polski XVI-XVIII w. Sześć propozycji problemowych”, in Symbolae Historiae Artium. Studia z historii sztuki Lechowi Kalinowskiemu dedykowane (Warsaw: 1986) 369-379.

116 Krótka Nauka Budownicza Dworów Pataców Zamków podtug Nieba y zwyczaiu Polskiego, (Krakow: 1659); cf. Miłobędzki A. (ed.), Krótka Nauka Budownicza Dworów Pałaców Zamków podtug Nieba y zwyczaiu Polskiego (Wrocław: 1957). 
being unpractical, and not fulfilling defensive objectives, but most of all, as being ill-suited to the Polish custom!117 In the end, he uses à rebours the argument deployed by the earlier authors, that it is the warriors, not the walls, that are the true defence, and the army to guard a castle can only be mounted by the wealthiest lords. Still, the Polish patrons were obviously moved more by the rhetoric of some Sarmatian historians and their admiration for medieval virtues than by the sensible advice of building professionals and theoreticians.

The evidence presented above seems to suggest that the attitudes to a medieval past and medieval architecture among the elites of the Polish-Lithuanian Commonwealth (as far as these opinions can be reconstructed) were embedded in a number of distinct, and often contradictory, discourses. For the majority of the nobles, the sense of the past was literally incorporated in the figures and deeds of the ancestors. One's family history and the narratives construed around the accomplishments of one's forefathers were used to inspire the subsequent generations of the szlachta in their contribution to the repeated cycle of life. The awareness of the historical significance of the 'middle ages' was thus a rare phenonomenon among contemporary Poles, who were also much more at ease with classical antiquity than their own past, mainly due to texts which formed the backbone of early modern education. Lacking comparable written sources concerning the local 'dark ages', Poles had to rely on the available material evidence to grasp it. Late medival architecture seemed to offer a perfect instrument of such inquiry, as it offered a spectacular corroboration for claims of greatness of the nation and verified the might of each aristocractic clan. Not surprisingly, the castle, as a building type largely defined in the second half of the fourteenth century under Casimir the Great, remained a powerful sign of the past and provided an important point of reference for early modern patrons. Yet there was a tension between the discourse of appreciation of medieval monuments and the chivalric values they embodied and one of the aspects of the ideology of Sarmatism, which gradually gained ground in the Commonwealth after the end of the Jagiellonian monarchy. Sarmatism, with its cult of an ancient nomadic tribe of Sarmatians as putative ancestors of the szlachta, served to devalue the role of architecture in construction of national/class identity. Ancient Sarmatians did not build houses and met their enemies in the open field - hence Poles, as their descendants, were persuaded by many contemporary thinkers to disregard the role of residences or fortifications. The quest for social status embodied by the traditional form of a castle, however, proved unrelenting in the Commonwealth throughout the early

117 Krótka Nauka Budownicza (1957 ed.) 16-18. 
modern period, with those lacking the aristocratic pedigree particularly eager to employ medieval forms as a means of legitimization.

\section{Selected Bibliography}

Andrzejewski A. - Kajzer L., "Modernizations of Medieval Castles and the Problem of 'palazzo in fortezza' in Great Poland in the 15th-17th Centuries", in Caune A. - Ose I. (eds.), Castella Maris Baltici (Riga: 2007) 9-18.

Arciszewska B., "The royal residence in Wilanów and gender constructions in early modern Poland", in Frommel S. (ed.), Homme bâtisseur, femme bâtisseuse: traditions et stratégies dans le monde occidental et oriental (Paris: 2013) 137-150.

Arciszewska B., "The 'Polish roof' and 'the Polish attic' in architectural history of early modern Poland", in Chatenet M. - Gady A (eds.), Toits d'Europe, Formes, structures, décors, identités, usages du toit à lâge moderne (XV', XVI ${ }^{e}, X V I I^{e}$ siècles) (Paris: 2016) $153^{-172 .}$

Arciszewska B., "Vicenzo Scamozzi and modernization of architecture in PolishLithuanian Commonwealth", in Barbieri F. - Avagnina M.E. - Sanvito P. (eds.), Vincenzo Scamozzi Teoretico Europeo (Vicenza: 2016), 230-252.

Bardach J., “Uwagi o 'rodowym' ustroju społeczeństwa i prawie bliższości w Polsce średniowiecznej”, Czasopismo Prawno-Historyczne 4 (1952) 407-458.

Bielski M., Kronika polska, ed. J. Bielski (Krakow, Jacob Siebeneycher: 1597).

Bogucka M., "Uwagi o postrzeganiu czasu w Rzeczpospolitej szlacheckiej XVI-XVII wieku”, in Cackowski Z. - Wojczakowski J. (eds.), Stosunek do czasu w różnych strukturach kulturowych (Warsaw: 1987) 347-373.

Bogucka M., "Between the West and the East: The Outline of the Polish Cultural Identity Formation Till the End of the 18th Century", in Grathoff R. - Kłoskowska A. (eds.), The Neighbourhood of Cultures (Warsaw: 1994) 53-61.

Bogucka M., The Lost World of the Sarmatians, Custom as the Regulator of Polish Social Life in Early Modern Times (Warsaw: 1996).

Buko A., The Archaeology of Early Medieval Poland, Discoveries, Hypotheses, Interpretations (Leiden: 2008).

Chrościcki J., Sztuka i polityka. Funkcje propagandowe sztuki w epoce Wazów 1587-1668 (Warsaw: 1983).

Crossley P., Gothic Architecture in the Reign of Casimir the Great: Church Architecture in Lesser Poland 1320-1380 (Krakow: 1985).

de' Crescenzi Pietro, O pomnożeniu y rozkrzewieniu wszelakich pożytków ksiag dwoienaście, ed. J. Ponętowski, trans. A. Trzecieski (Krakow, Stanislaus Scharffenberger: 1571). 
Dybaś B., Fortece Rzeczypospolitej. Studium z dziejów budowy fortyfikacji statych w państwie polsko-litewskim w XVII wieku (Toruń: 1998).

Fabiański M., "O genezie architektury pałacu Krzyżtopór w Ujeździe i jego dekoracji”, Biuletyn Historii Sztuki 58 (1996) 269-278.

Frycz-Modrzewski A., O poprawie Rzeczypospolitej księgi czwore (Łosk: 1577).

Górnicki Łukasz, O elekcyi, wolności, prawie i obyczajach polskich: rozmowa Polaka z Wtochem (Krakow, U dziedziców Jakuba Siebeneychera: 1616).

Grzybkowski A., Gotycka architektura murowana w Polsce (Warsaw: 2014).

Guerquin B., Zamki w Polsce (Warsaw: 1984).

Jakimowicz T., "Turris Pyothrkoviensis - pałac Zygmunta I", Kwartalnik Architektury $i$ Urbanistyki 17 (1972) 21-38.

Jakimowicz T., "Rezydencja w Polsce w wieku XVI. Stan i potrzeby badań", Kwartalnik Architektury i Urbanistyki: teoria i historia 24, 4 (1979) 311-337.

Jakimowicz T., Dwór murowany w Polsce w wieku XVI (wieża - kamienica - kasztel) (Warsaw: 1979).

Jakimowicz T., "Sibi et posteritate'. Treści ideowe rezydencji feudalnej w Polsce XVIXIX w.", in Opaliński E. - Wiślicz T. (eds.), Rezydencje $w$ średniowieczu i czasach nowożytnych (Warsaw: 2001) 252-267.

Kajzer L., "Z problematyki badań założeń typu palazzo in fortezza w Polsce”, in Czyż A.S. (ed.), Architektura znaczeń. Studia ofiarowane prof. Zbigniewowi Bani w 65 rocznice urodzin iw 4o-lecie pracy dydaktycznej (Warsaw: 2011), 64-75.

Kiersnowski R., "Tworzywo historyczne polskich legend herbowych", Rocznik Polskiego Towarzystwa Heraldycznego 13, 2 (1995) 11-25.

Kotowicz-Borowy I., "Znaczenie tradycji etosu szlacheckiego w poczuciu tożsamości grupowej i narodowej na dawnych pograniczach Rzeczypospolitej", Pogranicze. Studia spoteczne 19 (2012) 33-59.

Kowalczyk J., “Rezydencje późnobarokowe na Wołyniu”, Przegląd Wschodni 4 (1997) 25-73.

Kromer Marcin, De origine et rebus gestis Polonorum libri XXX (Basel, Johannes Oporinus: 1555).

Kwiatkowski S., "O kształtowaniu obrazu epoki średniowiecza," in Skibiński P. Przeszowska A. (eds.), Spojrzenie w przeszłość (Warsaw: 2007) 135-153.

Kuls T., Krzyżtopór (Warsaw: 2014).

Kunicki W., Obraz szlachcica polskiego (Krakow, Jacob Siebeneycher: 1615).

Kurtyka J., "Posiadłość, dziedziczność i prestiż. Badania nad późnośredniowieczną i wczesnonowożytną wielką własnością możnowładczą w Polsce XIV-XVII wieku”, Roczniki Historyczne 65 (1999), 161-194.

Lasek P., Turris fortissima nomen Domini. Murowane wieże mieszkalne w Królestwie Polskim od 1300 r. do potowy XVI w. (Warsaw: 2013). 
Lasek P., "Zamki elity monarchii Andegawenów po obu stronach Karpat. Próba wstępnej charakterystyki kastellologicznej", in Zamki w Karpatach (Krosno: 2014) 27-44.

Meyer N., "Krzyżtopór - der Herrscher als Festung. Eine anthropomorphe Deutung der Residenz des Krzysztof Ossoliński in Ujazd”, Biuletyn Historii Sztuki 55 (1993) 467-481.

Miłobędzki A., "Pałac i zamek 'renesansowy”, in Jaroszewski T. (ed.), Renesans. Sztuka i ideologia (Warsaw: 1976) 411-420.

Miłobędzki A., "Tradycja średniowieczna w polskiej rezydencji nowożytnej”, Kwartalnik Architektury i Urbanistyki 24 (1979) 339-345.

Miłobędzki A., "Architektura Królestwa Polskiego w XV wieku", in Skubiszewski P. (ed.), Sztuka i ideologia XV wieku (Warsaw: 1978) 461-477.

Miłobędzki A., Architektura polska XVII wieku (Warsaw: 1980).

Miodońska B., "Władca i państwo w krakowskim drzeworycie książkowym XVI w.", in Jaroszewski T. (ed.), Renesans. Sztuka i ideologia (Warsaw: 1976) 45-96.

Moser D.R., "Mittelalter als Wissenschaftskonstruktion und Fiktion der Moderne", in Segl P. (ed.), Mittelalter und Moderne. Entdeckung und Rekonstruktion der mittelalterlichen Welt (Sigmaringen: 1997) 223-227.

Mrozowski P., Polskie nagrobki gotyckie (Warsaw: 1994).

Olszacki T., "Rezydencje królewskie prowincji Małopolskiej w XIV wieku - możliwości interpretacji”, in Architektura. Czasopismo Techniczne 108, 23 (2011), 251-297.

Paprocki B., Gniazdo Cnoty zkad herby rycerstwa stawnego (Krakow, Andrzej Piotrkowczyk: 1578).

Ratajczak T., "Podróże władcy i architektura. Przebudowa królewskich rezydencji za panowania Zygmunta Starego", Artium Quaestiones 17 (2006) 5-37.

Rolska-Boruch I., 'Domy Pańskie’ na Lubelszczyźnie od późnego gotyku do wczesnego baroku (Lublin: 2003).

Rutkowski H., "Zamek w Piotrkowie”, Kwartalnik Architektury i Urbanistyki 3, 2 (1958) $155^{-176 .}$

Starowolski Szymon, Votum o naprawie Rzeczypospolitey, (Kraków, Maciej Jędrzejowczyk: 1625).

Starowolski S., Sarmatiae Bellatores (Cologne, Henricus Crithius: 1631).

Starowolski S., Prywat Polska kiervie (Krakow, Łukasz Kupisz: 1649).

Starowolski S., Wojownicy Sarmaccy, trans. and ed. J. Starnawski (Warsaw: 1979).

Szymczak J., "Koszty murowanego budownictwa obronnego w Polsce do XVI wieku", Kwartalnik Historii Kultury Materialnej 36, 2 (1988) 233-275.

Szymczak J., "Zamki i pieniądze w średniowiecznej Polsce”, in Antoniewicz M. (ed.), Zamki i przestrzeń społeczna w Europie Środkowej i Wschodniej (Warsaw: 2002) 13-23. Śnieżko D., "Swojskie i obce w kronice uniwersalnej (przykład Marcina Bielskiego)", Teksty Drugie 79 (2003) 23-40. 
Tazbir J., “Czas w kulturze staropolskiej”, in Tazbir J. (ed.), Studia nad kultura staropolska (Krakow: 2001), 176-196.

Tazbir J., "Wzorce osobowe szlachty polskiej w XVII wieku", Kwartalnik Historyczny 83, $4(1976) 784-797$.

Torbus T., "Architektura siedzib Zygmunta Starego jako wyraz dbałości o wizerunek dynastii", in Mrozowski - Tyszka - Węcowski (eds.), Europa Jagiellonica 1386-1572. Sztuka, kultura i polityka w Europie Środkowej za panowania Jagiellonów (Warsaw: 2015) 161-196.

Wyrozumski J., Kazimierz Wielki (Wrocław: 2004).

Zaniewski P., Zamki Kazimierza Wielkiego (Kraków: ARCo 2012). 